\title{
Experimental Investigation of Cold-formed Lean Duplex Stainless Steel Beam-columns
}

\author{
Yuner Huang and Ben Young*
}

Department of Civil Engineering, The University of Hong Kong, Pokfulam Road, Hong Kong, China

\begin{abstract}
This paper describes a test program on cold-formed lean duplex stainless steel members in combined compression and minor axis bending. The test specimens were cold-rolled from flat strips of lean duplex stainless steel grade EN 1.4162. In this study, square and rectangular hollow sections were compressed at different eccentricities, in order to obtain a beam-column interaction curve for each series of tests. Initial overall geometric imperfections of the members were measured prior to testing. The ultimate loads and the failure modes of each specimen were obtained. The observed failure modes include local buckling, flexural buckling and interaction of local and flexural buckling. The test strengths obtained from this study and other available data were compared with the design strengths predicted by the American Specification, Australian/New Zealand Standard and European Code for stainless steel structures. It should be noted that these specifications do not cover the material of lean duplex stainless steel. Therefore, the suitability of the beam-column design rules in these specifications for lean duplex stainless steel is assessed in this study. Generally, these specifications are capable of predicting the beam-column strengths of the lean duplex stainless steel test specimens, and the design rules in the specifications are considered to be reliable. It is observed that the European Code generally provides quite conservative predictions for the beam-column specimens compared to the American Specification and Australian/New Zealand Standard predictions.
\end{abstract}

Keywords: Beam-columns; Cold-formed; Lean duplex; Stainless steel; Structural design

\footnotetext{
${ }^{*}$ Corresponding author. Tel.: +852-2859-2674; fax: +852-2559-5337.

E-mail address: young@hku.hk (B. Young).
} 


\section{Introduction}

Cold-formed lean duplex stainless steel, with both structural and economical advantages, is becoming an attractive choice as a construction material. It has a low nickel content compared to other grades of stainless steel, which reduced the material cost. In addition, it is regarded as a high strength material with the nominal yield strength $(0.2 \%$ proof stress) of $450 \mathrm{MPa}$. However, investigation of such relatively new material is very limited. Huang and Young [1] investigated the material properties of cold-formed lean duplex stainless steel, including the yield strength, ultimate strength, Young's modulus, residual stress, local imperfection, and stub column strengths. Huang and Young [2, 3] as well as Theofanous and Gardner [4] carried out experimental and numerical investigations on cold-formed lean duplex stainless steel columns. It is found that the current design specifications generally provide conservative predictions to the column strengths of cold-formed lean duplex stainless steel. Modified column design rules based on the current design specifications have been proposed. Huang and Young [5] as well as Theofanous and Gardner [6] investigated the structural behaviour of cold-formed lean duplex stainless steel flexural members. The flexural strengths of the structural members obtained from experimental and numerical investigations were compared with the design strengths predicted by different design rules. It is found that the existing design rules are generally conservative for the lean duplex stainless steel beams, and beam design rules were also proposed.

Structural members subjected to combined compression and bending are commonly used in construction. Previous researchers have investigated stainless steel structural members subjected to axial compression and bending. Kouhi et al. [7] carried out tests on beam-column specimens of rectangular hollow section (RHS) for austenitic stainless steel grade EN 1.4301 (AISI 304). The test results were compared with the design strengths calculated by European Code. It is suggested that the limitation of the magnification factor should be ignored for a more conservative and less scattered predictions. Macdonald et al. [8] conducted beam-column tests on lipped channel section for austenitic stainless steel grade EN 1.4301. It is found that interaction formula in European Code provides very conservative predictions for the beam-column strengths, when the virgin $0.2 \%$ proof stress and the linear elastic moment capacity were used. The predictions can be improved by using the $0.2 \%$ proof stress obtained from the fabricated sections, which include the strength enhancement due to cold-working, together with the moment capacity obtained from the beam tests. Greiner and Kettler [9] evaluated the interaction factor in the interaction formulae for the prediction of 
beam-column strengths in EC3 Part 1.4 [10]. Numerical simulations for I-sections and hollow sections of austenitic stainless steel (grade EN 1.4301) and duplex stainless steel (grade EN 1.4462) beam-column specimens were performed. A set of interaction factors for stainless steel beam-columns is proposed for different sections. It is found that the interaction formulae for carbon steel are also suitable for stainless steel, when the proposed interaction factors are used. Lui et al. [11] conducted a series of tests on cold-formed duplex stainless steel grade EN 1.4462 (S32205). The beam-column test strengths were compared with design strengths predicted by the American Specification (ASCE) [12] and Australian/New Zealand Standard (AS/NZS) [13] for stainless steel. It is found that the current design specifications are generally conservative for the duplex stainless steel beam-columns. Talja and Salmi [14] conducted beam-column tests for cold-formed RHS of austenitic stainless steel grade EN 1.4301. The test results were compared with the design strengths calculated by the beam-column design rules in the EC3 Part 1.3 [15]. It is suggested that the limitation for magnification factor in the interaction formulae should not be used.

It should be noted that there is no investigation on cold-formed lean duplex stainless steel beam-column members up to now. The purpose of this paper is to provide test data on cold-formed lean duplex stainless steel members in combined axial compression and bending. Furthermore, the suitability of the current design rules in the American Specification (ASCE) [12], Australian/New Zealand Standard (AS/NZS) [13] and European Code (EC3) [16] for cold-formed lean duplex stainless steel beam-columns is assessed. Lastly, the beam-column design rules were evaluated using reliability analysis.

\section{Test specimens}

Cold-formed lean duplex stainless steel members were tested under combined compression and bending in this study. The cold-formed lean duplex stainless steel grade EN 1.4162 is considered to be a high strength material with nominal $0.2 \%$ proof stress of $450 \mathrm{MPa}$ [17]. The test specimens were cold-rolled from flat strips into four different cross-sections, including two square hollow sections (SHS) and two rectangular hollow sections (RHS). The nominal section sizes $(D \times B \times t)$ of the SHS and RHS are $50 \times 50 \times 1.5,50 \times 50 \times 2.5,100 \times 50 \times 2.5$ and $150 \times 50 \times 2.5$, where $D, B$ and $t$ are the depth, width and thickness of the cross-sections in millimeter, respectively. Each specimen was cut to a specified length of either 550 or 1550 $\mathrm{mm}$. Both ends of the specimens were milled flat and then welded to $20 \mathrm{~mm}$ thick steel end 
plates for the specimens to be connected to the end bearings. Four different cross-sections with two different column lengths for each section provided eight series of beam-column tests. The specimens were compressed by different eccentricities that ranged from around 2 to $55 \mathrm{~mm}$, in order to obtain a beam-column interaction curve for each series of tests. A total of 37 beam-column specimens were tested in this study.

The test specimens were labeled such that the nominal cross-section geometry, specimen length, and loading eccentricities could be identified, as shown in Tables 1 - 8. For example, the label " $50 \times 50 \times 1.5 \mathrm{~L} 550 \mathrm{E} 55 \mathrm{R}$ " defines the following specimen: the dimension before the letter " $\mathrm{L}$ " indicates the nominal cross-section geometry $(D \times B \times t)$ of the specimen; the letter " $L$ " indicates the length of the specimen, and the following digits represent the nominal length of the specimen in millimeters $(550 \mathrm{~mm})$; the following part of the label "E55" indicates the nominal loading eccentricity at the ends of the specimen (55 mm); and if a test was repeated, then the last letter " $R$ " indicates the repeated test. The measured loading eccentricities and cross-section dimensions of each test specimen are shown in Tables $1-8$. The cross-section dimensions in Tables $1-8$ are the average measured values at both ends of each test specimen.

The material properties of the test specimens were determined by tensile coupon tests on the flat portions of the cross-sections, as detailed in Huang and Young [1]. The tensile coupons were extracted from the same batch as the beam-column specimens in this study. The material properties obtained from the coupon tests, including the static $0.2 \%$ proof stress $\left(\sigma_{0.2}\right)$, static tensile strength $\left(\sigma_{u}\right)$, initial Young's modulus $\left(E_{o}\right)$, elongation at fracture $\left(\varepsilon_{f}\right)$ and Ramberg-Osgood parameter $(n)$, are summarized in Table 9.

\section{Geometric imperfection measurements}

Initial overall geometric imperfections of the beam-column specimens were measured prior to testing. Theodolite was used to obtain readings at the mid-length and near both ends of the specimens. The geometric imperfections were measured at the flat width near the corner, as shown in Fig. 1. The overall geometric imperfections at mid-length $(\delta)$ are normalized by the specimen length $(L)$, as summarized in Table 10. The sign convention of the overall geometric imperfections and the location of measurement are shown in Fig. 1. The average absolute value of the overall geometric imperfections at mid-length were 1/1968, 1/4333, 
$1 / 2172,1 / 2577,1 / 2490,1 / 4227,1 / 1979$, and $1 / 7179$ of the specimen length for specimens in test Series $50 \times 50 \times 1.5 \mathrm{~L} 550,50 \times 50 \times 1.5 \mathrm{~L} 1550,50 \times 50 \times 2.5 \mathrm{~L} 550, \quad 50 \times 50 \times 2.5 \mathrm{~L} 1550$, $100 \times 50 \times 2.5 \mathrm{~L} 550,100 \times 50 \times 2.5 \mathrm{~L} 1550,150 \times 50 \times 2.5 \mathrm{~L} 550$ and $150 \times 50 \times 2.5 \mathrm{~L} 1550$, respectively.

The maximum initial local geometric imperfections of the specimens measured by Huang and Young [1] were $0.31,0.101,0.348$ and $0.679 \mathrm{~mm}$ for cross-sections $50 \times 50 \times 1.5,50 \times 50 \times 2.5$, $100 \times 50 \times 2.5$ and $150 \times 50 \times 2.5$, respectively. These specimens were also from the same batch as the beam-column specimens in this study. The local geometric imperfection measurements are detailed in Huang and Young [1].

\section{Combined compression and bending tests}

\subsection{Test setup and test procedure}

The cold-formed lean duplex stainless steel members were compressed between pinned ends with different eccentricities. A hydraulic testing machine was used to apply compressive force to the specimens. The test rig and the test setup are shown in Fig. 2. The specimens were welded with end plates. The pin-ended bearings were used at both upper and lower end supports to allow free rotation of the specimens about the minor axis only. Each pin-ended bearing is made up of knife-edge wedge plate and pit plate. The wedge plate has slot holes to allow adjustment of the column specimen to be loaded at a specified eccentricity. One of the pit plates was connected to a rigid plate at the upper end support, while the other pit plate was connected to a special bearing at the lower end support. The end plates of the specimen were bolted to the two knife-edge wedge plates. The specimen was then put into the testing machine between the two pit plates, so that the knife-edge of the lower wedge plate was seated on the V-shape pit of the lower pit plate. Initially, the special bearing was free to rotate in any direction. The lower and upper wedges were positioned in-line and then applied approximately $5 \mathrm{kN}$ to the specimen. This procedure would eliminate any possible gaps between the wedge plates and the pit plates in the pin-ended bearings, since the special bearing was free to rotate in any direction. The special bearing was then restrained from twisting and rotation by using the horizontal and vertical bolts, respectively. The applied load on the specimens was then released to approximately $2 \mathrm{kN}$ to allow the test starts with a small initial load. The small compression load ensures full contact in the pin-ended bearings. 
Three displacement transducers (LVDTs) were used to measure the axial shortening and the end rotation of the specimens. In addition, displacement transducers were located horizontally at mid-length of the specimens to measure the horizontal deflection of the specimen about the bending axis. Strain gauges were attached in the axial direction at mid-length of the specimens to determine the loading eccentricity and local buckling. Four strain gauges were located on the webs near the corners for all specimens to determine the loading eccentricity. Two additional strain gauges were located in the middle of the webs for columns having specimen length of 550mm to observe the occurrence of local buckling. Displacement control was used to drive the hydraulic actuator at a constant speed of 0.2 $\mathrm{mm} / \mathrm{min}$ for all tests. The static load was recorded by pausing the applied straining for $2 \mathrm{~min}$ near the ultimate load and post-ultimate load. A data acquisition system was used to record the applied load, the readings of the LVDTs and strain gauges at regular intervals during the tests.

\subsection{Loading eccentricity}

It is important to measure the eccentricity $(e)$ accurately, in order to compare the test strengths directly with the design strengths calculated from the measured loading eccentricity. Prior to the tests, the distance between the minor axis of the specimens and the knife edge of the wedge plate was adjusted to a specified eccentricity. Four strain gauges and a displacement transducer were used to determine the loading eccentricity at the mid-length of the specimens during testing. The applied load, longitudinal strains and overall deflection at mid-length about the bending axis of the specimens were recorded to determine the loading eccentricity. The bending moment of the specimens at mid-length equals to $E_{o} I_{y} \kappa$, and also equals to the applied compressive load $(P)$ multiply by the loading eccentricity $(e+\delta)$ together with the lateral deflection $(\Delta)$. Therefore, the measured loading eccentricity is determined as $(e+\delta)=\left(E_{o} I_{y} \kappa / P-\Delta\right)$, where $E_{o}=$ initial Young's modulus; $I_{y}=$ second moment area of the sections about the minor axis; $\kappa=$ curvature of the specimens which was calculated using the readings of the strain gauges; $P=$ applied compressive load; and $\Delta=$ overall horizontal deflection at mid-length of the specimens about the bending axis. The measured loading eccentricity was obtained for each specimen during the initial stage of loading in the elastic range of the tests, as shown in Tables 1-8. 


\subsection{Test results}

The experimental ultimate axial loads $\left(P_{E x p}\right)$, end moments $\left(M_{\text {end,Exp }}\right)$, second-order elastic moments $\left(M_{e, E x p}\right)$ and inelastic moments $\left(M_{i, \text { Exp }}\right)$ corresponding to ultimate axial loads, and the failure modes of the beam-column tests are shown in Tables 11-18. The end moment $\left(M_{\text {end,Exp }}\right)$ corresponding to the ultimate axial load equals to the ultimate axial load $\left(P_{\text {Exp }}\right)$ multiply by loading eccentricity $(e+\delta)$. The inelastic moment $\left(M_{i, \text { Exp }}\right)$ and second-order elastic moment $\left(M_{e, E x p}\right)$ corresponding to the ultimate axial load are calculated by Eq. (1) and (2), respectively.

$$
\begin{gathered}
M_{i, \text { Exp }}=P_{E x p}\left(e+\delta+\Delta_{u}\right) \\
M_{e, E x p}=\frac{M_{e n d, E x p}}{1-\frac{P_{E x p}}{P_{e}}}
\end{gathered}
$$

where $\Delta_{u}$ is the overall horizontal deflection at mid-length of the specimen at ultimate axial load; and $P_{e}$ is the elastic buckling load. The curves of the axial load $(P)$ versus the inelastic moment as well as the axial load versus the end moment for Series $50 \times 50 \times 1.5 \mathrm{~L} 550$ and Series 50×50×1.5L1550 are shown in Figs. 3 and 4, respectively. The points corresponding to the ultimate axial load $\left(P_{E x p}\right)$ on the axial load versus inelastic moment curves are also indicated by the symbol circles, as shown in Figs. 3 and 4. It is observed from Figs. 3 and 4 that the second order effect on the long specimens of Series $50 \times 50 \times 1.5 \mathrm{~L} 1550$ is significant compared to the end moment, while it is less significant on the shorter specimens of Series $50 \times 50 \times 1.5 \mathrm{~L} 550$. Similar phenomenon was also observed for other test series. This is because the overall deflection about the bending axis was large for the long specimens, and relatively small for the shorter specimens.

The failure modes observed at ultimate load of the specimens involved local buckling (L), flexural buckling (F) and interaction of local and flexural buckling (L+F). Fig. 5(a) and Fig. 5(b) show the flexural buckling and interaction of local and flexural buckling for specimens $50 \times 50 \times 2.5 \mathrm{~L} 1550 \mathrm{E} 5$ and $150 \times 50 \times 2.5 \mathrm{~L} 1550 \mathrm{E} 25$, respectively. For the beam-column specimens in this study, flexural buckling was observed for the test specimens in Series $50 \times 50 \times 1.5 \mathrm{~L} 1550,50 \times 50 \times 2.5 \mathrm{~L} 550,50 \times 50 \times 2.5 \mathrm{~L} 1550$ and $100 \times 50 \times 2.5 \mathrm{~L} 1550$. Interaction 
of local and flexural buckling was observed for the test specimens in Series 50×50×1.5L550, $100 \times 50 \times 2.5 \mathrm{~L} 550,150 \times 50 \times 2.5 \mathrm{~L} 550$ and $150 \times 50 \times 2.5 \mathrm{~L} 1550$.

\section{Reliability analysis}

The reliability of the beam-column design rules in the current specifications, including ASCE [12], AS/NZS [13] and EC3 [16], was evaluated using reliability analysis. Reliability analysis is detailed in the Commentary of the ASCE Specification [12]. A target reliability index of 2.5 for stainless steel structural members is used as a lower limit in this study. The design rules are considered to be reliable if the reliability index is greater than or equal to 2.5. The resistance factors $\left(\phi_{0}\right)$ of $0.85,0.90$ and 0.91 for the design axial strength, and $0.90,0.90$ and 0.91 for design flexural strength as recommended by the ASCE [12], AS/NZS [13] and EC3 [16] specifications, respectively, were used in the reliability analysis. The load combinations of 1.2DL+1.6LL, 1.25DL+1.5LL and 1.35DL+1.5LL were used in the reliability analysis for ASCE [12], AS/NZS [13] and EC3 [16], respectively, where DL is the dead load and LL is the live load. The Eq. 6.2-2 in the ASCE Specification was used in calculating the reliability index. The statistical parameters $M_{m}=1.10, F_{m}=1.00, V_{M}=0.10$ and $V_{F}=0.05$, which are the mean values and coefficients of variation for material properties and fabrication factors for compression members and flexural members, in the commentary of the ASCE Specification were adopted. The mean value $\left(P_{m}\right)$ and coefficient of variation $\left(V_{P}\right)$ of the tested-to-predicted load and moment ratios are shown in Tables 11-18 for each test series, and Table 19 for all test specimens. In calculating the reliability index, the correction factor Eq. F1.1-3 in the North American Specification for the design of cold-formed steel structural members AISI S100 [18] was used to account for the influence due to a small number of tests. For the purpose of direct comparison, constant resistant factors $\left(\phi_{1}\right)$ of 0.85 for compression members and 0.9 for flexural members, as well as a load combination of $1.2 \mathrm{DL}+1.6 \mathrm{LL}$ in the ASCE Specification were used to calculate the reliability index $\left(\beta_{1}\right)$. The values of the reliability index are also shown in Tables 11-18 for each test series, and Table 19 for all test specimens. 


\section{Design rules and comparison with beam-column strengths}

\subsection{General}

The unfactored design strengths (nominal strengths) for members subjected to combined compression and bending were calculated using the following three specifications:

- American Society of Civil Engineers (ASCE) Specification [12] for the design of cold-formed stainless steel structural members.

- Australian/New Zealand Standard (AS/NZS) [13] for cold-formed stainless steel structures.

- European Code (EC3) [16]: Design of steel structure - Part 1.4: General rules Supplementary rules for stainless steels.

The effective length $\left(l_{e}\right)$ of the beam-column specimens was assumed to be equal to the length between the two ends of the wedges, as shown in Fig. 2. The effective length of the beam-column specimens are shown in Tables 11-18. The design strengths were calculated using the average measured cross-section dimensions and the measured material properties for each specimen as detailed in Tables 1-9. The design rules provided in these three specifications for stainless steel members under combined axial load and bending for SHS and RHS are described in this Section. It should be noted that these specifications do not cover the material of lean duplex stainless steel. Therefore, the current beam-column design rules for lean duplex stainless steel are assessed in this study.

The test strengths are compared with the unfactored design strengths (nominal strengths) for the combined compression and bending tests as shown in Tables 11-19, where $P_{A S C E}, P_{A S / N Z S}$, $P_{E C 3}, M_{A S C E}, M_{A S / N Z S}$ and $M_{E C 3}$ are the design axial loads and design second-order elastic moments predicted using the ASCE Specification [12], AS/NZS Standard [13], and EC3 Code [16] for stainless steel structures. The available test strengths of cold-formed lean duplex stainless steel columns [2] and flexural members [5] of the same batch of specimens as the beam-column specimens are also used in the comparison, in order to investigate the full range of beam-column interaction curve for each series of tests. The second-order elastic moments corresponding to ultimate axial loads obtained from the tests are calculated using Eq. (2), where $P_{E x p}$ and $M_{\text {end,Exp }}$ are the experimental ultimate axial load and the 
corresponding end moment. The test strengths are compared with the interaction curves obtained from the three specifications as shown in Figs. 6-13, where the vertical axis shows the axial compressive load normalized with the load at yielding $\left(P_{y}\right)$, which is equal to $0.2 \%$ proof stress $\left(\sigma_{0.2}\right)$ multiplied by the full cross-section area $(A)$, and the horizontal axis shows the second-order elastic moment $\left(M_{e, u}\right)$ normalized with the plastic moment $\left(M_{p l}\right)$ that is equal to $0.2 \%$ proof stress $\left(\sigma_{0.2}\right)$ multiplied by plastic modulus $\left(W_{p l}\right)$.

\subsection{American Specification}

The unfactored beam-column strengths (nominal strengths) for the SHS and RHS members subjected to axial compression and minor axis bending in the ASCE Specification [12] are calculated by Eqs. $(3-5)$ in this study,

$$
\begin{aligned}
& \frac{P_{u}}{P_{n}}+\frac{C_{m} M_{e, u}}{M_{n}} \leq 1.0 \\
& \frac{P_{u}}{P_{n o}}+\frac{M_{\text {end,u }}}{M_{n}} \leq 1.0 \\
& \frac{P_{u}}{P_{n}}+\frac{M_{\text {end,u }}}{M_{n}} \leq 1.0 \quad \text { (when } \frac{P_{u}}{P_{n}} \leq 0.15 \text { ) }
\end{aligned}
$$

where $P_{u}$ is the design axial compressive strength; $M_{e, u}$ is the design second-order elastic moment, which is calculated by $M_{e, u}=M_{e n d, u} /\left(1-P_{u} / P_{e}\right) ; M_{e n d, u}$ is the design end moment, which is calculated by the design axial compressive strength $\left(P_{u}\right)$ multiplying by loading eccentricity $(e+\delta) ; C_{m}$ is a coefficient and taken as 1.0 in this study; $P_{n}$ and $M_{n}$ are the nominal axial strength and flexural strength calculated by the design rules for columns and beams in the ASCE [12], respectively; $P_{n o}$ is the nominal axial strength taken the buckling stress as the yield stress in the ASCE [12]. In this study, the design axial compressive strength $\left(P_{u}\right)$ and design second-order elastic moment $\left(M_{e, u}\right)$ in the ASCE [12] are represented by $P_{A S C E}$ and $M_{A S C E}$, respectively, as shown in Tables 11-19.

The design beam-column strengths are compared with the test strengths, as shown in Tables 11 - 19. The design axial strengths $\left(P_{A S C E}\right)$ and flexural strengths $\left(M_{A S C E}\right)$ calculated from Eqs. (3 - 5) are conservative for all beam-column specimens, except for specimens $150 \times 50 \times 2.5 \mathrm{~L} 550 \mathrm{E} 5$ and $150 \times 50 \times 2.5 \mathrm{~L} 550 \mathrm{E} 12.5$. The mean values of $P_{E x p} / P_{A S C E}$ ratio ranged from 1.00 to 1.20 , and the values of COV from 0.031 to 0.074 for the eight test series, while 
the mean values of $M_{e, E x p} / M_{A S C E}$ ratio ranged from 1.04 to 1.28 with the values of COV ranged from 0.040 to 0.169 for the eight test series. The reliability indices ( $\beta_{0}$ and $\beta_{1}$ ) of $P_{E x p} / P_{A S C E}$ are greater than the target value of 2.5 for all series, while those of $M_{e, E x p} / M_{A S C E}$ are also greater than the target value for all series except for Series $50 \times 50 \times 1.5 \mathrm{~L} 1550$, $50 \times 50 \times 2.5 \mathrm{~L} 1550$ and $150 \times 50 \times 2.5 \mathrm{~L} 550$, as shown in Tables $11-18$. The $P_{E x p} / P_{A S C E}$ and $M_{e, E x p} / M_{A S C E}$ ratios for all specimens are equal to 1.09 and 1.16 , with the corresponding values of COV equal to 0.080 and 0.125 , respectively, as shown in Table 19.

\subsection{Australian/New Zealand Standard}

The beam-column design rules in AS/NZS Standard [13] are identical to those in the ASCE Specification [12], except that the nominal axial strength $\left(P_{n}\right)$ and flexural strength $\left(M_{n}\right)$ are calculated in accordance with the design rules for columns and beams in the AS/NZS [13], respectively. The explicit method (alternative method) in Section 3.4.2 of the AS/NZS Standard [13] was used in calculating the nominal axial strength $\left(P_{n}\right)$ in this study. The design axial compressive strength $\left(P_{u}\right)$ and design second-order elastic moment $\left(M_{e, u}\right)$ in the AS/NZS [13] are represented by $P_{A S / N Z S}$ and $M_{A S / N Z S}$, respectively, as shown in Tables 11-19.

The beam-column design rules in the AS/NZS [13] are conservative for all beam-column specimens. The mean values of $P_{E x p} / P_{A S / N Z S}$ ratio ranged from 1.06 to 1.27 with the values of COV ranged from 0.010 to 0.058 . The mean values of $M_{e, E x p} / M_{A S / N Z S}$ ratio ranged from 1.11 to 1.41 , and the values of $\mathrm{COV}$ ranged from 0.043 to 0.199 . The reliability indices ( $\beta_{0}$ and $\beta_{1}$ ) of $P_{E x p} / P_{A S / N Z S}$ and $M_{e, E x p} / M_{A S / N Z S}$ are greater than the target value for all test series, except for $\beta_{0}$ of $M_{e, E x p} / M_{A S / N Z S}$ in Series $100 \times 50 \times 2.5 \mathrm{~L} 1550$, as shown in Tables $11-18$. It is also shown in Table 19 that the design rules in AS/NZS Standard are conservative for cold-formed lean duplex stainless steel beam-column specimens in this study, where $P_{E x p} / P_{A S / N Z S}$ and $M_{e, E x p} / M_{A S / N Z S}$ ratios equal to 1.16 and 1.30 , and the corresponding values of COV equal to 0.065 and 0.130 , respectively.

\subsection{European Code}

According to clause 5.5 of the EC3 Part 1.4 [16], the interaction equation for members subjected to axial compression and minor axis bending is shown in Eq. (6),

$$
\frac{P_{u}}{P_{n}}+k_{z}\left(\frac{M_{e n d, u}+P_{u} e_{N}}{\beta_{W} W_{p l} f_{y}}\right) \leq 1.0
$$


where $P_{u}$ is the design axial compressive strength; $M_{e n d, u}$ is the design end moment, which is calculated as the design axial compressive strength $\left(P_{u}\right)$ multiplying by loading eccentricity $(e$ $+\delta$ ); $P_{n}$ is the nominal axial strength calculated by the design rules for columns in the EC3 [16]; $e_{N}$ is the shifts in the neutral axes when the cross-section is subject to uniform compression, which is taken as zero for the RHS and SHS in this study. $\beta_{W}$ is the coefficient, $W_{p l}$ is the plastic modulus of full cross-section, $f_{y}$ is the yield stress, and $k_{z}$ is the interaction factor. Section classification of the specimens is required to calculate the design strengths. The design axial compressive strength $\left(P_{u}\right)$ calculated using Eq. (6) is represented by $P_{E C 3}$ in this study, as shown in Tables 11-19. Unlike the ASCE Specification [12] and AS/NZS Standard [13], the EC3 [16] does not require the multiplication of $1 /\left(1-P_{u} / P_{e}\right)$ in the calculation of design strengths in Eq. (6). For comparison purposes, the design second-order elastic moment $\left(M_{E C 3}\right)$ is calculated by the end moment $\left(M_{e n d, u}\right)$ multiplied by $1 /\left(1-P_{u} / P_{e}\right)$. Hence, $M_{E C 3}=M_{e n d, u} /\left(1-P_{u} / P_{e}\right)$, as shown in Tables $11-19$.

The design rules in EC3 [16] are conservative for all the beam-column specimens, except for specimen $150 \times 50 \times 2.5 \mathrm{~L} 550 \mathrm{E} 12.5$ with $P_{E x p} / P_{E C 3}$ and $M_{e, E x p} / M_{E C 3}$ both equal to 0.99 . The mean values of $P_{E x p} / P_{E C 3}$ ratio ranged from 1.02 to 1.34 , with the values of COV ranged from 0.026 to 0.130 ; while the mean values of $M_{e, E x p} / M_{E C 3}$ ratio ranged from 1.06 to 1.83 , with the values of COV ranged from 0.076 to 0.303 . The reliability indices $\left(\beta_{0}\right.$ and $\beta_{1}$ ) of $P_{\text {Exp }} / P_{E C 3}$ and $M_{e, E x p} / M_{E C 3}$ are greater than the target value for all test series, except for $\beta_{0}$ and $\beta_{1}$ of $M_{e, E x p} / M_{E C 3}$ in Series $100 \times 50 \times 2.5 \mathrm{~L} 1550, \beta_{0}$ of $P_{E x p} / P_{E C 3}$ and $M_{e, E x p} / M_{E C 3}$ in Series $150 \times 50 \times 2.5 \mathrm{~L} 550$, and $\beta_{0}$ of $M_{e, E x p} / M_{E C 3}$ in Series $150 \times 50 \times 2.5 \mathrm{~L} 1550$, as shown in Tables 11-18. Overall, the design rules in EC3 [16] are conservative for the cold-formed lean duplex stainless steel beam-column specimens in this study. The $P_{E x p} / P_{E C 3}$ and $M_{e, E x p} / M_{E C 3}$ ratios equal to 1.22 and 1.47 with the corresponding values of COV equal to 0.103 and 0.234 , respectively, as shown in Table 19.

Generally speaking, the EC3 Code [16] provides the most conservative and scattered predictions. The interaction factor $\left(k_{z}\right)$ affected the shape of the interaction curves. The conservative predictions of the beam-column strengths were mainly contributed by the conservative predictions of the axial strengths and flexural strengths in the EC3. 


\section{Conclusions}

A test program on cold-formed lean duplex stainless steel square and rectangular hollow sections subjected to combined axial compression and minor axis bending was conducted. Eight series of test specimens with various eccentricities were tested. The test strengths were compared with the design strengths calculated by the American, Australian/New Zealand, and European specifications. The normalized beam-column interaction curves of the design strengths predicted by the three specifications as well as the test strengths were plotted. It should be noted that these three specifications do not cover the material of lean duplex stainless steel, and thus their applicability in designing lean duplex stainless steel beam-columns was assessed. Generally, the current design specifications are conservative and reliable in predicting the beam-column strengths of cold-formed lean duplex stainless steel in this study. It is shown that the European Code provides the most conservative and scattered predictions compared to the American Specification and Australian/New Zealand Standard.

\section{Acknowledgements}

The authors are grateful to STALA Tube Finland for supplying the test specimens. The authors are also thankful to Mr. Chi-Kin CHEUNG for his assistance in the experimental program as part of his final year undergraduate research project at The University of Hong Kong. The research work described in this paper was supported by a grant from The University of Hong Kong under the seed funding program for basic research. 


\section{Notation}

The following symbols are used in this paper:

A full area

$B \quad$ overall width of specimen

$b_{\text {eff }} \quad$ effective width

$C_{m} \quad$ coefficient in American Specification and Australian/New Zealand Standard

COV coefficient of variation

D overall depth of specimen

$E_{o} \quad$ initial Young's modulus

e eccentricity

$e_{N} \quad$ shift in the neutral axes for cross-section subjected to uniform compression

$F_{m} \quad$ mean value of fabrication factor

Iy second moment area about the minor axis

$k \quad$ effective length factor or plate buckling coefficient

$k_{z} \quad$ interaction factor

L $\quad$ specimen length

$l_{e} \quad$ effective length of specimen

M moment

$M_{m} \quad$ mean value of material factor

$M_{A S C E} \quad$ unfactored design second-order elastic moment of beam-column for American Specification

$M_{A S / N Z S}$ unfactored design second-order elastic moment of beam-column for Australian/New Zealand Standard

$M_{E C 3}$ unfactored design second-order elastic moment of beam-column for European Code

$M_{e, E x p} \quad$ experimental second-order elastic moment corresponding to ultimate load

$M_{e, u} \quad$ design second-order elastic moment corresponding to ultimate load 
$M_{\text {end,Exp }} \quad$ experimental end moment corresponding to ultimate load

$M_{\text {end,u }} \quad$ design end moment corresponding to ultimate load

$M_{i, E x p} \quad$ experimental inelastic moment corresponding to ultimate load

$M_{i, u} \quad$ design inelastic moment corresponding to ultimate load

$M_{n} \quad$ nominal flexural strength

$M_{p l} \quad$ plastic moment

$M_{u} \quad$ design flexural strength

$M_{1} \quad$ smaller moment at the ends of specimen

$M_{2} \quad$ larger moment at the ends of specimen

$n \quad$ Ramberg-Osgood parameter

P $\quad$ applied compression load

$P_{e} \quad$ elastic buckling load

$P_{\text {ASCE }} \quad$ unfactored design axial load of beam-column for American Specification

$P_{\text {AS/NZS }} \quad$ unfactored design axial load of beam-column for Australian/New Zealand Standard

$P_{E C 3} \quad$ unfactored design axial load of beam-column for European Code

$P_{\text {Exp }} \quad$ experimental ultimate axial load

$P_{m} \quad$ mean value of tested-to-predicted load ratio

$P_{n} \quad$ nominal strength of compressive member

$P_{n o} \quad$ nominal strength of compressive member calculated by the American Specification with the buckling stress taken as yield stress

$P_{u} \quad$ design axial compressive strength

$P_{y} \quad$ axial load at yielding

$r_{i} \quad$ inner corner radius of specimen

$r_{o} \quad$ outer corner radius of specimen

$t \quad$ thickness of specimen

$V_{F} \quad$ coefficient of variation of fabrication factor

$V_{m} \quad$ coefficient of variation of material factor 


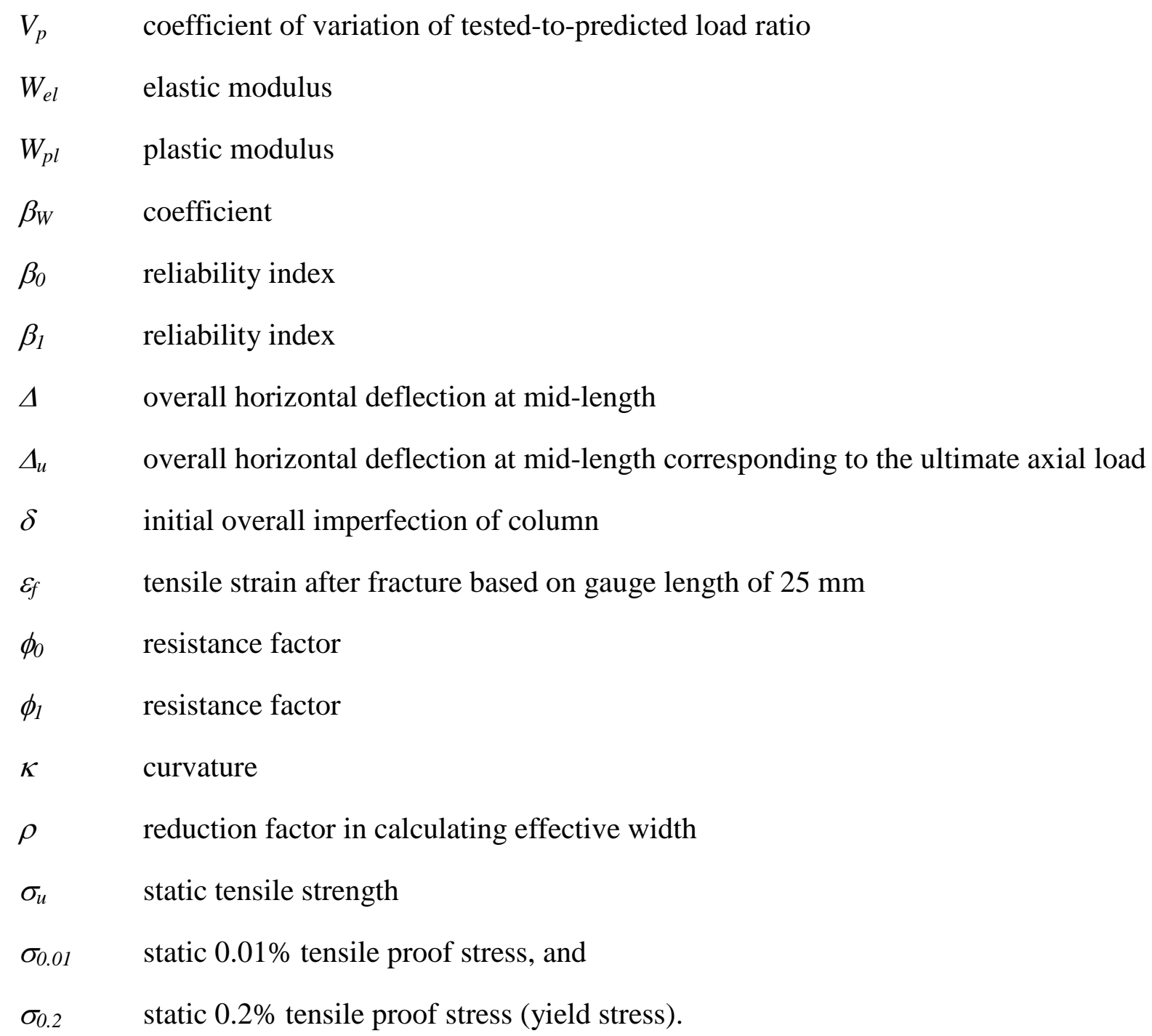




\section{References}

[1] Huang Y, Young B. Material properties of cold-formed lean duplex stainless steel sections. Thin-walled Structures 2012a; 54: 72-81.

[2] Huang Y, Young B. Tests of pin-ended cold-formed lean duplex stainless steel columns. Journal of Constructional Steel Research 2013; 82: 203-215.

[3] Huang Y, Young B. Structural performance of cold-formed lean duplex stainless steel columns. Proceeding of 4th International Structural Stainless Steel Experts Seminar 2012b.

[4] Theofanous M, Gardner L. Testing and numerical modelling of lean duplex stainless steel hollow section columns. Journal of Engineering Structures 2009; 31(12): 3047-3058.

[5] Huang Y, Young B. Experimental and numerical investigation of cold-formed lean duplex stainless steel flexural members. Thin-walled Structures (in press)

[6] Theofanous M, Gardner L. Experimental and numerical studies of lean duplex stainless steel beams. Journal of Constructional Steel Research 2010; 66(6): 816-25.

[7] Kouhi J, Talja A, Salmi P, Ala-Outinen T. Current R\&D work on the use of stainless steel in construction in Finland. Journal of Constructional Steel Research 2000; 54(1): 31-50.

[8] Macdonald M, Rhodes J, Kotelko M. Stainless steel stub columns subject to combined bending and axial loading. Thin-walled Structures 2007; 45(10-11): 893-897.

[9] Greiner R, Kettler M. Interaction of bending and axial compression of stainless steel members. Journal of Constructional Steel Research 2008; 64(11): 1217-24.

[10] EC3. Design of steel structures - Part 1-4: General rules-Supplementary rules for stainless steel. European Committee for Standardization, EN 1993-1-4, Brussels; 2005.

[11] Lui WM, Young B, Ashrah M. Eccentric compression tests on high strength duplex stainless steel columns. Proceeding of $14^{\text {th }}$ International Symposium on Tubular Structures 2012.

[12] ASCE. Specification for the design of cold-formed stainless steel structural members. SEI/ASCE 8-02; Reston, VA: American Society of Civil Engineers; 2002.

[13] AS/NZS. Cold-formed stainless steel structures. Australian/New Zealand Standard, AS/NZS 4673:2001. Sydney (Australia): Standards Australia; 2001.

[14] Talja A, Salmi P. Design of stainless steel RHS beams, columns and beam-columns. VTT Building Technology, Finland; 1995. 
[15] EC3. Design of steel structures, Part 1.3: Cold formed thin gauge members and sheeting. European Committee for Standardization (document CEN/TC250/SC3: N269E), ENV 1993-1-3 (Draft), Brussels; 1993.

[16] EC3. Design of steel structures - Part 1.4: General rules - Supplementary rules for stainless steels. European Committee for Standardization, ENV 1993-1-4, CEN, Brussels; 2006.

[17] Yrjola P. Stainless steel hollow sections handbook. Finnish Constructional Steelwork Association, Finland, 2008.

[18] AISI S100. North American Specification for the design of cold-formed steel structural members. North American Cold-formed Steel Specification, American Iron and Steel Institute, AISI S100-2007, Washington, D.C.; 2007. 


\begin{tabular}{r|ccccccc}
\hline \multicolumn{1}{c|}{ Specimen } & $\begin{array}{c}D \\
(\mathrm{~mm})\end{array}$ & $\begin{array}{c}B \\
(\mathrm{~mm})\end{array}$ & $\begin{array}{c}t \\
(\mathrm{~mm})\end{array}$ & $\begin{array}{c}r_{o} \\
(\mathrm{~mm})\end{array}$ & $\begin{array}{c}r_{i} \\
(\mathrm{~mm})\end{array}$ & $\begin{array}{c}A \\
\left(\mathrm{~mm}^{2}\right)\end{array}$ & $\begin{array}{c}e+\delta \\
(\mathrm{mm})\end{array}$ \\
\hline C2L550 & 50.6 & 50.6 & 1.493 & 3.0 & 1.0 & 286.0 & 0.48 \\
$50 \times 50 \times 1.5 \mathrm{~L} 550 \mathrm{E} 5$ & 50.1 & 50.2 & 1.529 & 2.8 & 2.0 & 290.1 & 5.58 \\
$50 \times 50 \times 1.5 \mathrm{~L} 550 \mathrm{E} 12.5$ & 50.1 & 50.1 & 1.512 & 2.7 & 1.7 & 287.1 & 11.91 \\
$50 \times 50 \times 1.5 \mathrm{~L} 550 \mathrm{E} 25$ & 50.1 & 50.1 & 1.515 & 2.8 & 1.6 & 288.2 & 23.60 \\
$50 \times 50 \times 1.5 \mathrm{~L} 550 \mathrm{E} 55$ & 50.1 & 50.2 & 1.522 & 3.0 & 1.9 & 288.7 & 50.13 \\
$50 \times 50 \times 1.5 \mathrm{~L} 550 \mathrm{E} 55 \mathrm{R}$ & 50.0 & 50.2 & 1.512 & 3.0 & 1.9 & 288.6 & 50.59 \\
$50 \times 50 \times 1.5 \mathrm{~L} 900^{\#}$ & 50.2 & 50.2 & 1.527 & 3.0 & 1.0 & 290.2 & -- \\
\hline Mean & 50.2 & 50.2 & 1.516 & 2.9 & 1.6 & 288.4 & --- \\
COV & 0.004 & 0.004 & 0.008 & 0.045 & 0.268 & 0.005 & --- \\
\hline
\end{tabular}

Note: ${ }^{*}$ Test results from Huang and Young [2]; ${ }^{\#}$ Test results from Huang and Young [5]

Table 1: Measured eccentricities and specimen dimensions of Series 50×50×1.5L550

\begin{tabular}{r|ccccccc}
\hline \multicolumn{1}{c|}{ Specimen } & $\begin{array}{c}D \\
(\mathrm{~mm})\end{array}$ & $\begin{array}{c}B \\
(\mathrm{~mm})\end{array}$ & $\begin{array}{c}t \\
(\mathrm{~mm})\end{array}$ & $\begin{array}{c}r_{o} \\
(\mathrm{~mm})\end{array}$ & $\begin{array}{c}r_{i} \\
(\mathrm{~mm})\end{array}$ & $\begin{array}{c}A \\
\left(\mathrm{~mm}^{2}\right)\end{array}$ & $\begin{array}{c}e+\delta \\
(\mathrm{mm})\end{array}$ \\
\hline C2L1550 & 50.8 & 50.8 & 1.510 & 2.8 & 1.0 & 292.1 & 0.48 \\
$50 \times 50 \times 1.5 \mathrm{~L} 1550 \mathrm{E} 2$ & 50.2 & 50.2 & 1.532 & 2.7 & 1.4 & 292.4 & 1.71 \\
$50 \times 50 \times 1.5 \mathrm{~L} 1550 \mathrm{E} 5$ & 50.2 & 50.2 & 1.555 & 3.1 & 1.0 & 298.0 & 5.96 \\
$50 \times 50 \times 1.5 \mathrm{~L} 1550 \mathrm{E} 12.5$ & 50.2 & 50.0 & 1.535 & 3.0 & 1.3 & 292.5 & 12.86 \\
$50 \times 50 \times 1.5 \mathrm{~L} 1550 \mathrm{E} 25$ & 50.0 & 50.4 & 1.522 & 3.0 & 1.7 & 289.7 & 23.46 \\
$50 \times 50 \times 1.5 \mathrm{~L} 1550 \mathrm{E} 55$ & 50.1 & 50.2 & 1.433 & 2.7 & 1.8 & 273.0 & 51.06 \\
$50 \times 50 \times 1.5 \mathrm{~L} 900^{\#}$ & 50.2 & 50.2 & 1.527 & 3.0 & 1.0 & 290.2 & --- \\
\hline Mean & 50.3 & 50.3 & 1.516 & 2.9 & 1.3 & 289.7 & --- \\
COV & 0.005 & 0.005 & 0.026 & 0.060 & 0.246 & 0.027 & -- \\
\hline
\end{tabular}

Note: ${ }^{*}$ Test results from Huang and Young [2]; ${ }^{*}$ Test results from Huang and Young [5]

Table 2: Measured eccentricities and specimen dimensions of Series 50×50×1.5L1550 


\begin{tabular}{|c|c|c|c|c|c|c|c|}
\hline Specimen & $\begin{array}{c}D \\
(\mathrm{~mm})\end{array}$ & $\begin{array}{c}B \\
(\mathrm{~mm})\end{array}$ & $\begin{array}{c}t \\
(\mathrm{~mm})\end{array}$ & $\begin{array}{c}r_{o} \\
(\mathrm{~mm})\end{array}$ & $\begin{array}{c}r_{i} \\
(\mathrm{~mm})\end{array}$ & $\begin{array}{c}A \\
\left(\mathrm{~mm}^{2}\right)\end{array}$ & $\begin{array}{l}e+\delta \\
(\mathrm{mm})\end{array}$ \\
\hline C3L550* & 50.3 & 49.8 & 2.493 & 2.8 & 1.0 & 458.7 & 0.05 \\
\hline $50 \times 50 \times 2.5 \mathrm{~L} 550 \mathrm{E} 2$ & 50.2 & 49.7 & 2.549 & 3.2 & 1.0 & 472.8 & 2.58 \\
\hline $50 \times 50 \times 2.5 \mathrm{~L} 550 \mathrm{E} 5$ & 50.2 & 49.6 & 2.514 & 3.1 & 1.0 & 466.6 & 5.37 \\
\hline $50 \times 50 \times 2.5 \mathrm{~L} 550 \mathrm{E} 12.5$ & 50.1 & 49.7 & 2.504 & 3.3 & 1.0 & 464.9 & 11.49 \\
\hline $50 \times 50 \times 2.5 \mathrm{~L} 550 \mathrm{E} 25$ & 50.1 & 49.7 & 2.503 & 3.2 & 1.0 & 464.5 & 24.09 \\
\hline $50 \times 50 \times 2.5 \mathrm{~L} 550 \mathrm{E} 55$ & 50.1 & 49.5 & 2.485 & 3.3 & 1.0 & 460.4 & 49.68 \\
\hline $50 \times 50 \times 2.5 \mathrm{~L} 900^{\#}$ & 50.1 & 50.0 & 2.487 & 3.0 & 1.0 & 457.4 & --- \\
\hline Mean & 50.1 & 49.7 & 2.505 & 3.1 & 1.0 & 463.6 & $\begin{array}{ll}-- \\
---\end{array}$ \\
\hline $\mathrm{COV}$ & 0.002 & 0.003 & 0.009 & 0.056 & 0.000 & 0.011 & --- \\
\hline
\end{tabular}

Note: ${ }^{*}$ Test results from Huang and Young [2]; ${ }^{*}$ Test results from Huang and Young [5]

Table 3: Measured eccentricities and specimen dimensions of Series 50×50×2.5L550

\begin{tabular}{|c|c|c|c|c|c|c|c|}
\hline Specimen & $\begin{array}{c}D \\
(\mathrm{~mm})\end{array}$ & $\begin{array}{c}B \\
(\mathrm{~mm})\end{array}$ & $\begin{array}{c}t \\
(\mathrm{~mm})\end{array}$ & $\begin{array}{c}r_{o} \\
(\mathrm{~mm})\end{array}$ & $\begin{array}{c}r_{i} \\
(\mathrm{~mm})\end{array}$ & $\begin{array}{c}A \\
\left(\mathrm{~mm}^{2}\right)\end{array}$ & $\begin{array}{l}e+\delta \\
(\mathrm{mm})\end{array}$ \\
\hline C3L1550* & 50.3 & 49.9 & 2.489 & 2.8 & 1.0 & 460.1 & 0.55 \\
\hline $50 \times 50 \times 2.5 \mathrm{~L} 1550 \mathrm{E} 5$ & 50.2 & 49.5 & 2.488 & 3.2 & 1.0 & 461.2 & 4.45 \\
\hline $50 \times 50 \times 2.5 \mathrm{~L} 1550 \mathrm{E} 12.5$ & 50.1 & 49.7 & 2.500 & 3.3 & 1.0 & 464.1 & 11.40 \\
\hline $50 \times 50 \times 2.5 \mathrm{~L} 1550 \mathrm{E} 25$ & 50.2 & 49.6 & 2.540 & 3.3 & 1.0 & 470.9 & 23.32 \\
\hline $50 \times 50 \times 2.5 \mathrm{~L} 1550 \mathrm{E} 55$ & 50.2 & 49.5 & 2.523 & 3.1 & 1.0 & 467.3 & 55.38 \\
\hline $50 \times 50 \times 2.5 \mathrm{~L} 900^{\#}$ & 50.1 & 50.0 & 2.487 & 3.0 & 1.0 & 457.4 & --- \\
\hline Mean & 50.2 & 49.7 & 2.505 & 3.1 & 1.0 & 463.5 & $\begin{array}{ll}-- \\
--\end{array}$ \\
\hline $\mathrm{COV}$ & 0.002 & 0.005 & 0.009 & 0.066 & 0.000 & 0.011 & -- \\
\hline
\end{tabular}

Note: ${ }^{*}$ Test results from Huang and Young [2]; ${ }^{*}$ Test results from Huang and Young [5]

Table 4: Measured eccentricities and specimen dimensions of Series 50×50×2.5L1550 


\begin{tabular}{r|ccccccc}
\hline \multicolumn{1}{c|}{ Specimen } & $\begin{array}{c}D \\
(\mathrm{~mm})\end{array}$ & $\begin{array}{c}B \\
(\mathrm{~mm})\end{array}$ & $\begin{array}{c}t \\
(\mathrm{~mm})\end{array}$ & $\begin{array}{c}r_{o} \\
(\mathrm{~mm})\end{array}$ & $\begin{array}{c}r_{i} \\
(\mathrm{~mm})\end{array}$ & $\begin{array}{c}A \\
\left(\mathrm{~mm}^{2}\right)\end{array}$ & $\begin{array}{c}e+\delta \\
(\mathrm{mm})\end{array}$ \\
\hline C5L550 & 100.1 & 50.5 & 2.487 & 3.3 & 1.0 & 709.3 & 0.03 \\
$100 \times 50 \times 2.5 \mathrm{~L} 550 \mathrm{E} 2$ & 100.2 & 50.0 & 2.529 & 3.3 & 1.0 & 724.3 & 2.31 \\
$100 \times 50 \times 2.5 \mathrm{~L} 550 \mathrm{E} 5$ & 100.2 & 50.2 & 2.510 & 3.7 & 1.0 & 719.6 & 4.26 \\
$100 \times 50 \times 2.5 \mathrm{~L} 550 \mathrm{E} 12.5$ & 100.2 & 50.1 & 2.523 & 3.3 & 1.0 & 723.0 & 11.02 \\
$100 \times 50 \times 2.5 \mathrm{~L} 550 \mathrm{E} 25$ & 100.1 & 50.0 & 2.500 & 3.0 & 1.0 & 715.7 & 23.75 \\
$100 \times 50 \times 2.5 \mathrm{~L} 550 \mathrm{E} 55$ & 100.2 & 50.1 & 2.555 & 3.3 & 1.0 & 731.8 & 54.19 \\
$100 \times 50 \times 2.5 \mathrm{~L} 1500 N^{\#}$ & 100.1 & 50.7 & 2.480 & 3.5 & 1.0 & 708.3 & -- \\
\hline Mean & 100.2 & 50.2 & 2.512 & 3.3 & 1.0 & 718.9 & -- \\
COV & 0.000 & 0.005 & 0.010 & 0.063 & 0.000 & 0.012 & -- \\
\hline
\end{tabular}

Note: ${ }^{*}$ Test results from Huang and Young [2]; ${ }^{\#}$ Test results from Huang and Young [5]

Table 5: Measured eccentricities and specimen dimensions of Series 100×50×2.5L550

\begin{tabular}{r|ccccccc}
\hline \multicolumn{1}{c|}{ Specimen } & $\begin{array}{c}D \\
(\mathrm{~mm})\end{array}$ & $\begin{array}{c}B \\
(\mathrm{~mm})\end{array}$ & $\begin{array}{c}t \\
(\mathrm{~mm})\end{array}$ & $\begin{array}{c}r_{o} \\
(\mathrm{~mm})\end{array}$ & $\begin{array}{c}r_{i} \\
(\mathrm{~mm})\end{array}$ & $\begin{array}{c}A \\
\left(\mathrm{~mm}^{2}\right)\end{array}$ & $\begin{array}{c}e+\delta \\
(\mathrm{mm})\end{array}$ \\
\hline $\begin{array}{r}\text { C5L1550 } \\
\text { 100×50×2.5L1550E5 }\end{array}$ & 100.2 & 50.4 & 2.510 & 3.5 & 1.2 & 716.8 & 0.18 \\
$100 \times 50 \times 2.5 \mathrm{~L} 1550 \mathrm{E} 12.5$ & 100.2 & 50.0 & 2.526 & 3.4 & 1.0 & 723.3 & 11.32 \\
$100 \times 50 \times 2.5 \mathrm{~L} 1550 \mathrm{E} 25$ & 100.2 & 50.1 & 2.534 & 3.5 & 1.0 & 725.7 & 25.36 \\
$100 \times 50 \times 2.5 \mathrm{~L} 1550 \mathrm{E} 55$ & 100.1 & 50.2 & 2.523 & 3.3 & 1.0 & 722.8 & 54.94 \\
$100 \times 50 \times 2.5 \mathrm{~L} 1500 N^{\#}$ & 100.1 & 50.7 & 2.480 & 3.5 & 1.0 & 708.3 & --- \\
\hline Mean & 100.2 & 50.2 & 2.517 & 3.4 & 1.0 & 720.2 & --- \\
COV & 0.000 & 0.006 & 0.008 & 0.02 & 0.079 & 0.009 & --- \\
\hline
\end{tabular}

Note: ${ }^{*}$ Test results from Huang and Young [2]; ${ }^{*}$ Test results from Huang and Young [5]

Table 6: Measured eccentricities and specimen dimensions of Series $100 \times 50 \times 2.5 \mathrm{~L} 1550$ 


\begin{tabular}{r|ccccccc}
\hline \multicolumn{1}{c|}{ Specimen } & $\begin{array}{c}D \\
(\mathrm{~mm})\end{array}$ & $\begin{array}{c}B \\
(\mathrm{~mm})\end{array}$ & $\begin{array}{c}t \\
(\mathrm{~mm})\end{array}$ & $\begin{array}{c}r_{o} \\
(\mathrm{~mm})\end{array}$ & $\begin{array}{c}r_{i} \\
(\mathrm{~mm})\end{array}$ & $\begin{array}{c}A \\
\left(\mathrm{~mm}^{2}\right)\end{array}$ & $\begin{array}{c}e+\delta \\
(\mathrm{mm})\end{array}$ \\
\hline $\begin{array}{r}\text { C6L550 } \\
\text { 150×50×2.5L550E5 }\end{array}$ & 150.1 & 50.2 & 2.490 & 4.5 & 2.0 & 953.0 & 0.50 \\
$150 \times 50 \times 2.5 \mathrm{~L} 550 \mathrm{E} 12.5$ & 150.0 & 49.8 & 2.493 & 5.1 & 2.7 & 954.3 & 13.01 \\
$150 \times 50 \times 2.5 \mathrm{~L} 550 \mathrm{E} 25$ & 150.0 & 49.5 & 2.484 & 5.1 & 2.3 & 951.0 & 23.60 \\
$150 \times 50 \times 2.5 \mathrm{~L} 550 \mathrm{E} 55$ & 150.0 & 49.8 & 2.519 & 4.3 & 1.8 & 967.7 & 55.25 \\
$150 \times 50 \times 2.5 \mathrm{~L} 1500 N^{\#}$ & 149.9 & 50.1 & 2.459 & 4.5 & 2.0 & 944.7 & --- \\
\hline Mean & 150.0 & 49.9 & 2.484 & 4.8 & 2.2 & 952.2 & -- \\
COV & 0.000 & 0.005 & 0.009 & 0.072 & 0.152 & 0.009 & -- \\
\hline
\end{tabular}

Note: ${ }^{*}$ Test results from Huang and Young [2]; ${ }^{*}$ Test results from Huang and Young [5]

Table 7: Measured eccentricities and specimen dimensions of Series 150×50×2.5L550

\begin{tabular}{r|ccccccc}
\hline \multicolumn{1}{c|}{ Specimen } & $\begin{array}{c}D \\
(\mathrm{~mm})\end{array}$ & $\begin{array}{c}B \\
(\mathrm{~mm})\end{array}$ & $\begin{array}{c}t \\
(\mathrm{~mm})\end{array}$ & $\begin{array}{c}r_{o} \\
(\mathrm{~mm})\end{array}$ & $\begin{array}{c}r_{i} \\
(\mathrm{~mm})\end{array}$ & $\begin{array}{c}A \\
\left(\mathrm{~mm}^{2}\right)\end{array}$ & $\begin{array}{c}e+\delta \\
(\mathrm{mm})\end{array}$ \\
\hline C6L1550 & 150.5 & 50.3 & 2.487 & 4.5 & 2.0 & 956.8 & 0.14 \\
$150 \times 50 \times 2.5 \mathrm{~L} 1550 \mathrm{E} 2$ & 149.9 & 49.8 & 2.509 & 4.9 & 2.3 & 961.2 & 2.23 \\
$150 \times 50 \times 2.5 \mathrm{~L} 1550 \mathrm{E} 5$ & 150.0 & 49.6 & 2.490 & 4.6 & 2.4 & 953.5 & 4.55 \\
$150 \times 50 \times 2.5 \mathrm{~L} 1550 \mathrm{E} 12.5$ & 150.1 & 49.6 & 2.491 & 5.3 & 2.7 & 952.5 & 11.58 \\
$150 \times 50 \times 2.5 \mathrm{~L} 1550 \mathrm{E} 25$ & 150.0 & 49.6 & 2.508 & 4.6 & 2.5 & 959.5 & 24.32 \\
$150 \times 50 \times 2.5 \mathrm{~L} 1550 \mathrm{E} 55$ & 150.0 & 49.8 & 2.541 & 4.0 & 2.5 & 972.4 & 55.45 \\
$150 \times 50 \times 2.5 \mathrm{~L} 1500 N^{\#}$ & 149.9 & 50.1 & 2.459 & 4.5 & 2.0 & 944.7 & -- \\
\hline Mean & 150.1 & 49.8 & 2.498 & 4.6 & 2.3 & 957.2 & --- \\
COV & 0.001 & 0.006 & 0.010 & 0.084 & 0.109 & 0.009 & --- \\
\hline
\end{tabular}

Note: ${ }^{*}$ Test results from Huang and Young [2]; ${ }^{*}$ Test results from Huang and Young [5]

Table 8: Measured eccentricities and specimen dimensions of Series $150 \times 50 \times 2.5 \mathrm{~L} 1550$

\begin{tabular}{cccccc}
\hline $\begin{array}{c}\text { Section } \\
(D \times B \times t)\end{array}$ & $\begin{array}{c}\sigma_{0.2} \\
(\mathrm{MPa})\end{array}$ & $\begin{array}{c}\sigma_{u} \\
(\mathrm{MPa})\end{array}$ & $\begin{array}{c}E_{o} \\
(\mathrm{GPa})\end{array}$ & $\begin{array}{c}\varepsilon_{f} \\
(\%)\end{array}$ & $n$ \\
\hline $50 \times 50 \times 1.5$ & 610 & 734 & 194 & 44 & 5 \\
$50 \times 50 \times 2.5$ & 635 & 756 & 198 & 44 & 6 \\
$100 \times 50 \times 2.5$ & 625 & 727 & 200 & 49 & 6 \\
$150 \times 50 \times 2.5$ & 664 & 788 & 202 & 35 & 4 \\
\hline
\end{tabular}

Table 9: Measured material properties obtained from tensile coupon tests [1] 


\begin{tabular}{|c|c|c|}
\hline Specimen & $\delta / L$ & $\begin{array}{c}\text { Specimen length } \\
\qquad L(\mathrm{~mm})\end{array}$ \\
\hline $50 \times 50 \times 1.5 \mathrm{~L} 550 \mathrm{E} 5$ & $1 / 2165$ & 550 \\
\hline $50 \times 50 \times 1.5 \mathrm{~L} 550 \mathrm{E} 12.5$ & $-1 / 1444$ & 550 \\
\hline $50 \times 50 \times 1.5 \mathrm{~L} 550 \mathrm{E} 25$ & $-1 / 2887$ & 550 \\
\hline $50 \times 50 \times 1.5 \mathrm{~L} 550 \mathrm{E} 55$ & $1 / 1732$ & 550 \\
\hline $50 \times 50 \times 1.5 \mathrm{~L} 550 \mathrm{E} 55 \mathrm{R}$ & $1 / 2165$ & 550 \\
\hline $50 \times 50 \times 1.5 \mathrm{~L} 1550 \mathrm{E} 2$ & $-1 / 4882$ & 1550 \\
\hline $50 \times 50 \times 1.5 \mathrm{~L} 1550 \mathrm{E} 5$ & $-1 / 6102$ & 1550 \\
\hline $50 \times 50 \times 1.5 \mathrm{~L} 1550 \mathrm{E} 12.5$ & $-1 / 3487$ & 1550 \\
\hline $50 \times 50 \times 1.5 \mathrm{~L} 1550 \mathrm{E} 25$ & $1 / 4724$ & 1550 \\
\hline $50 \times 50 \times 1.5 \mathrm{~L} 1550 \mathrm{E} 55$ & $1 / 3487$ & 1550 \\
\hline $50 \times 50 \times 2.5 \mathrm{~L} 550 \mathrm{E} 2$ & $-1 / 2835$ & 550 \\
\hline $50 \times 50 \times 2.5 \mathrm{~L} 550 \mathrm{E} 5$ & $-1 / 2362$ & 550 \\
\hline $50 \times 50 \times 2.5 \mathrm{~L} 550 \mathrm{E} 12.5$ & $1 / 1050$ & 550 \\
\hline $50 \times 50 \times 2.5 \mathrm{~L} 550 \mathrm{E} 25$ & $-1 / 3487$ & 550 \\
\hline $50 \times 50 \times 2.5 \mathrm{~L} 550 \mathrm{E} 55$ & $1 / 3487$ & 550 \\
\hline $50 \times 50 \times 2.5 \mathrm{~L} 1550 \mathrm{E} 5$ & $-1 / 3487$ & 1550 \\
\hline $50 \times 50 \times 2.5 \mathrm{~L} 1550 \mathrm{E} 12.5$ & $1 / 2835$ & 1550 \\
\hline $50 \times 50 \times 2.5 \mathrm{~L} 1550 \mathrm{E} 25$ & $1 / 2219$ & 1550 \\
\hline $50 \times 50 \times 2.5 \mathrm{~L} 1550 \mathrm{E} 55$ & $-1 / 2165$ & 1550 \\
\hline $100 \times 50 \times 2.5 \mathrm{~L} 550 \mathrm{E} 2$ & $-1 / 1082$ & 550 \\
\hline $100 \times 50 \times 2.5 \mathrm{~L} 550 \mathrm{E} 5$ & $-1 / 2887$ & 550 \\
\hline $100 \times 50 \times 2.5 \mathrm{~L} 550 \mathrm{E} 12.5$ & $-1 / 4882$ & 550 \\
\hline $100 \times 50 \times 2.5 \mathrm{~L} 550 \mathrm{E} 25$ & $1 / 4068$ & 550 \\
\hline $100 \times 50 \times 2.5 \mathrm{~L} 550 \mathrm{E} 55$ & $1 / 3487$ & 550 \\
\hline $100 \times 50 \times 2.5 \mathrm{~L} 1550 \mathrm{E} 5$ & $1 / 4068$ & 1550 \\
\hline $100 \times 50 \times 2.5 \mathrm{~L} 1550 \mathrm{E} 12.5$ & $-1 / 6102$ & 1550 \\
\hline $100 \times 50 \times 2.5 \mathrm{~L} 1550 \mathrm{E} 25$ & $1 / 4882$ & 1550 \\
\hline $100 \times 50 \times 2.5 \mathrm{~L} 1550 \mathrm{E} 55$ & $1 / 3015$ & 1550 \\
\hline $150 \times 50 \times 2.5 \mathrm{~L} 550 \mathrm{E} 5$ & $1 / 1082$ & 550 \\
\hline $150 \times 50 \times 2.5 \mathrm{~L} 550 \mathrm{E} 12.5$ & $-1 / 2835$ & 550 \\
\hline $150 \times 50 \times 2.5 \mathrm{~L} 550 \mathrm{E} 25$ & $1 / 2165$ & 550 \\
\hline $150 \times 50 \times 2.5 \mathrm{~L} 550 \mathrm{E} 55$ & $-1 / 3543$ & 550 \\
\hline $150 \times 50 \times 2.5 \mathrm{~L} 1550 \mathrm{E} 2$ & $-1 / 8136$ & 1550 \\
\hline $150 \times 50 \times 2.5 \mathrm{~L} 1550 \mathrm{E} 5$ & $-1 / 12205$ & 1550 \\
\hline $150 \times 50 \times 2.5 \mathrm{~L} 1550 \mathrm{E} 12.5$ & $1 / 6102$ & 1550 \\
\hline $150 \times 50 \times 2.5 \mathrm{~L} 1550 \mathrm{E} 25$ & $1 / 8136$ & 1550 \\
\hline $150 \times 50 \times 2.5 \mathrm{~L} 1550 \mathrm{E} 55$ & $-1 / 4882$ & 1550 \\
\hline
\end{tabular}

Table 10: Measured overall geometric imperfections at mid-length 


\begin{tabular}{|c|c|c|c|c|c|c|c|c|c|c|c|c|}
\hline \multirow[b]{2}{*}{ Specimen } & \multicolumn{5}{|c|}{ Test } & \multirow[b]{2}{*}{$\begin{array}{c}M_{e, E x p} \\
(\mathrm{kNmm})\end{array}$} & \multicolumn{6}{|c|}{ Comparison } \\
\hline & $\begin{array}{c}l_{e} \\
(\mathrm{~mm})\end{array}$ & $\begin{array}{l}\text { Failure } \\
\text { mode }\end{array}$ & $\begin{array}{l}P_{\text {Exp }} \\
(\mathrm{kN})\end{array}$ & $\begin{array}{c}M_{\text {end,Exp }} \\
(\mathrm{kNmm})\end{array}$ & $\begin{array}{c}M_{i, \text { Exp }} \\
(\mathrm{kNmm})\end{array}$ & & $\frac{P_{E x p}}{P_{A S C E}}$ & $\frac{P_{\text {Exp }}}{P_{A S / N Z S}}$ & $\frac{P_{E x p}}{P_{E C 3}}$ & $\frac{M_{e, \text { Exp }}}{M_{A S C E}}$ & $\frac{M_{e, E x p}}{M_{A S / N Z S}}$ & $\frac{M_{e, E x p}}{M_{E C 3}}$ \\
\hline $50 \times 50 \times 1.5 \mathrm{~L} 550 \mathrm{E} 5$ & 660 & $\mathrm{~L}+\mathrm{F}$ & 116.3 & 649.0 & 1396.4 & 856.8 & 1.15 & 1.21 & 1.29 & 1.20 & 1.28 & 1.38 \\
\hline $50 \times 50 \times 1.5 \mathrm{~L} 550 \mathrm{E} 12.5$ & 660 & $\mathrm{~L}+\mathrm{F}$ & 95.1 & 1132.6 & 1861.6 & 1413.2 & 1.21 & 1.27 & 1.36 & 1.27 & 1.33 & 1.45 \\
\hline $50 \times 50 \times 1.5 \mathrm{~L} 550 \mathrm{E} 55 \mathrm{R}$ & 660 & $\mathrm{~L}+\mathrm{F}$ & 42.1 & 2129.8 & 2529.7 & 2335.4 & 1.20 & 1.22 & 1.40 & 1.22 & 1.24 & 1.44 \\
\hline \multirow[t]{4}{*}{$50 \times 50 \times 1.5 \mathrm{~L} 900^{\#}$} & --- & $\mathrm{L}+\mathrm{F}$ & --- & --- & --- & 3336.6 & --- & --- & --- & 1.23 & 1.23 & 1.57 \\
\hline & & & & & & Mean $\left(P_{m}\right)$ & 1.17 & 1.22 & 1.34 & 1.21 & 1.26 & 1.43 \\
\hline & & & & & & $\operatorname{COV}\left(V_{P}\right)$ & 0.074 & 0.058 & 0.082 & 0.077 & 0.056 & 0.083 \\
\hline & & & & & Resistance & factor $\left(\phi_{0}\right)$ & 0.85 & 0.90 & 0.91 & 0.90 & 0.90 & 0.91 \\
\hline
\end{tabular}

Note: ${ }^{*}$ Test results from Huang and Young [2]; ${ }^{\#}$ Test results from Huang and Young [5]

$M_{\text {end,Exp }}=P_{E x p}(e+\delta) ; M_{i, E x p}=P_{E x p}\left(e+\delta+\Delta_{u}\right) ; M_{e, E x p}=M_{e n d, E x p} /\left(1-P_{E x p} / P_{e}\right)$

Table 11: Comparison of test strengths with design strengths for Series 50×50×1.5L550 


\begin{tabular}{|c|c|c|c|c|c|c|c|c|c|c|c|c|}
\hline \multirow[b]{2}{*}{ Specimen } & \multicolumn{5}{|c|}{ Test } & \multirow[b]{2}{*}{$\begin{array}{c}M_{e, \text { Exp }} \\
(\mathrm{kNmm})\end{array}$} & \multicolumn{6}{|c|}{ Comparison } \\
\hline & $\begin{array}{c}l_{e} \\
(\mathrm{~mm})\end{array}$ & $\begin{array}{c}\text { Failure } \\
\text { mode }\end{array}$ & $\begin{array}{l}P_{\text {Exp }} \\
(\mathrm{kN})\end{array}$ & $\begin{array}{c}M_{\text {end,Exp }} \\
(\mathrm{kNmm})\end{array}$ & $\begin{array}{c}M_{i, \text { Exp }} \\
(\mathrm{kNmm})\end{array}$ & & $\frac{P_{\text {Exp }}}{P_{A S C E}}$ & $\frac{P_{\text {Exp }}}{P_{A S / N Z S}}$ & $\frac{P_{E x p}}{P_{E C 3}}$ & $\frac{M_{e, \text { Exp }}}{M_{A S C E}}$ & $\frac{M_{e, E x p}}{M_{A S / N Z S}}$ & $\frac{M_{e, E \times p}}{M_{E C 3}}$ \\
\hline $50 \times 50 \times 1.5 \mathrm{~L} 1550 \mathrm{E} 2$ & 1660 & $\mathrm{~F}$ & 61.1 & 104.5 & 1294.7 & 477.0 & 1.02 & 1.12 & 1.22 & 1.07 & 1.57 & 1.99 \\
\hline $50 \times 50 \times 1.5 \mathrm{~L} 1550 \mathrm{E} 5$ & 1660 & $\mathrm{~F}$ & 52.8 & 314.9 & 1914.4 & 908.1 & 1.02 & 1.11 & 1.21 & 1.06 & 1.31 & 1.59 \\
\hline $50 \times 50 \times 1.5 \mathrm{~L} 1550 \mathrm{E} 55$ & 1660 & $\mathrm{~F}$ & 26.0 & 1327.6 & 2746.7 & 2070.8 & 1.18 & 1.23 & 1.41 & 1.27 & 1.36 & 1.64 \\
\hline \multirow[t]{5}{*}{$50 \times 50 \times 1.5 \mathrm{~L} 900^{\#}$} & --- & $\mathrm{L}+\mathrm{F}$ & --- & --- & --- & 3336.6 & --- & --- & --- & 1.23 & 1.23 & 1.55 \\
\hline & \multicolumn{6}{|r|}{ Mean $\left(P_{m}\right)$} & 1.05 & 1.13 & 1.26 & 1.09 & 1.32 & 1.70 \\
\hline & \multicolumn{6}{|r|}{$\operatorname{COV}\left(V_{P}\right)$} & 0.073 & 0.052 & 0.062 & 0.155 & 0.088 & 0.13 \\
\hline & \multicolumn{6}{|c|}{ Resistance factor $\left(\phi_{0}\right)$} & 0.85 & 0.90 & 0.91 & 0.90 & 0.90 & 0.909 \\
\hline & \multicolumn{6}{|c|}{ Reliability index $\left(\beta_{0}\right)$} & 2.80 & 2.77 & 3.17 & 2.25 & 3.21 & 3.75 \\
\hline
\end{tabular}

Note: ${ }^{*}$ Test results from Huang and Young [2]; ${ }^{\#}$ Test results from Huang and Young [5]

$M_{\text {end,Exp }}=P_{E x p}(e+\delta) ; M_{i, \text { Exp }}=P_{E x p}\left(e+\delta+\Delta_{u}\right) ; M_{e, \operatorname{Exp}}=M_{e n d, E x p} /\left(1-P_{E x p} / P_{e}\right)$

Table 12: Comparison of test strengths with design strengths for Series 50×50×1.5L1550 


\begin{tabular}{|c|c|c|c|c|c|c|c|c|c|c|c|c|}
\hline \multirow[b]{2}{*}{ Specimen } & \multicolumn{6}{|c|}{ Test } & \multicolumn{6}{|c|}{ Comparison } \\
\hline & $\begin{array}{c}l_{e} \\
(\mathrm{~mm})\end{array}$ & $\begin{array}{c}\text { Failure } \\
\text { mode }\end{array}$ & $\begin{array}{l}P_{\text {Exp }} \\
(\mathrm{kN})\end{array}$ & $\begin{array}{c}M_{\text {end,Exp }} \\
(\mathrm{kNmm})\end{array}$ & $\begin{array}{c}M_{i, \text { Exp }} \\
(\mathrm{kNmm})\end{array}$ & $\begin{array}{c}M_{e, \operatorname{Exp}} \\
(\mathrm{kNmm})\end{array}$ & $\frac{P_{E x p}}{P_{A S C E}}$ & $\frac{P_{\text {Exp }}}{P_{A S / N Z S}}$ & $\frac{P_{E x p}}{P_{E C 3}}$ & $\frac{M_{e, E \times p}}{M_{A S C E}}$ & $\frac{M_{e, E x p}}{M_{A S / N Z S}}$ & $\frac{M_{e, E \times p}}{M_{E C 3}}$ \\
\hline $50 \times 50 \times 2.5 \mathrm{~L} 550 \mathrm{E} 2$ & 660 & $\mathrm{~F}$ & 245.5 & 633.4 & 2243.0 & 929.2 & 1.11 & 1.21 & 1.12 & 1.17 & 1.31 & 1.18 \\
\hline $50 \times 50 \times 2.5 \mathrm{~L} 550 \mathrm{E} 5$ & 660 & $\mathrm{~F}$ & 217.2 & 1166.4 & 2928.1 & 1631.1 & 1.16 & 1.24 & 1.17 & 1.22 & 1.34 & 1.24 \\
\hline $50 \times 50 \times 2.5 \mathrm{~L} 550 \mathrm{E} 55$ & 660 & $\mathrm{~F}$ & 81.1 & 4467.8 & 5652.6 & 5012.9 & 1.34 & 1.37 & 1.58 & 1.38 & 1.42 & 1.65 \\
\hline \multirow[t]{4}{*}{$50 \times 50 \times 2.5 \mathrm{~L} 900^{\#}$} & --- & $\mathrm{F}$ & --- & --- & --- & 7000.8 & --- & --- & --- & 1.45 & 1.45 & 1.92 \\
\hline & & & & & & Mean $\left(P_{m}\right)$ & 1.20 & 1.27 & 1.27 & 1.28 & 1.38 & 1.43 \\
\hline & & & & & & $\operatorname{COV}\left(V_{P}\right)$ & 0.065 & 0.044 & 0.130 & 0.077 & 0.053 & 0.183 \\
\hline & & & & & Resistance & factor $\left(\phi_{0}\right)$ & 0.85 & 0.90 & 0.91 & 0.90 & 0.90 & 0.91 \\
\hline
\end{tabular}

Note: ${ }^{*}$ Test results from Huang and Young [2]; ${ }^{\#}$ Test results from Huang and Young [5]

$M_{\text {end,Exp }}=P_{E x p}(e+\delta) ; M_{i, E x p}=P_{E x p}\left(e+\delta+\Delta_{u}\right) ; M_{e, E x p}=M_{e n d, E x p} /\left(1-P_{E x p} / P_{e}\right)$

Table 13: Comparison of test strengths with design strengths for Series 50×50×2.5L550 


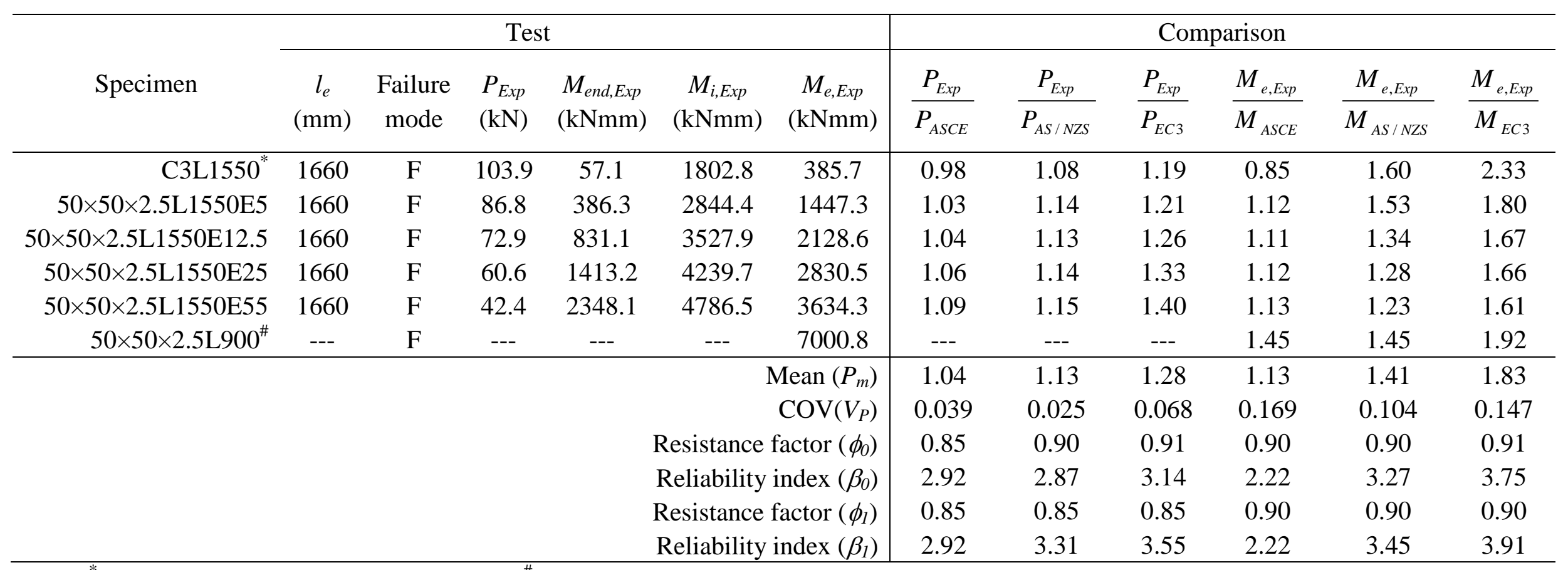

Note: ${ }^{*}$ Test results from Huang and Young [2]; ${ }^{\#}$ Test results from Huang and Young [5]

$M_{\text {end,Exp }}=P_{E x p}(e+\delta) ; M_{i, E x p}=P_{E x p}\left(e+\delta+\Delta_{u}\right) ; M_{e, E x p}=M_{e n d, E x p} /\left(1-P_{E x p} / P_{e}\right)$

Table 14: Comparison of test strengths with design strengths for Series 50×50×2.5L1550 


\begin{tabular}{|c|c|c|c|c|c|c|c|c|c|c|c|c|}
\hline \multirow[b]{2}{*}{ Specimen } & \multicolumn{5}{|c|}{ Test } & \multirow[b]{2}{*}{$\begin{array}{c}M_{e, \operatorname{Exp}} \\
(\mathrm{kNmm})\end{array}$} & \multicolumn{6}{|c|}{ Comparison } \\
\hline & $\begin{array}{c}l_{e} \\
(\mathrm{~mm})\end{array}$ & $\begin{array}{c}\text { Failure } \\
\text { mode }\end{array}$ & $\begin{array}{l}P_{\text {Exp }} \\
(\mathrm{kN})\end{array}$ & $\begin{array}{c}M_{\text {end,Exp }} \\
(\mathrm{kNmm})\end{array}$ & $\begin{array}{c}M_{i, \text { Exp }} \\
(\mathrm{kNmm})\end{array}$ & & $\frac{P_{E x p}}{P_{A S C E}}$ & $\frac{P_{E x p}}{P_{A S / N Z S}}$ & $\frac{P_{E x p}}{P_{E C 3}}$ & $\frac{M_{e, \text { Exp }}}{M_{A S C E}}$ & $\frac{M_{e, E x p}}{M_{A S / N Z S}}$ & $\frac{M_{e, E x p}}{M_{E C 3}}$ \\
\hline $100 \times 50 \times 2.5 \mathrm{~L} 550 \mathrm{E} 2$ & 660 & $\mathrm{~L}+\mathrm{F}$ & 325.7 & 752.4 & 1707.6 & 973.8 & 1.07 & 1.14 & 1.16 & 1.09 & 1.18 & 1.20 \\
\hline $100 \times 50 \times 2.5 \mathrm{~L} 550 \mathrm{E} 5$ & 660 & $\mathrm{~L}+\mathrm{F}$ & 294.7 & 1255.4 & 2377.2 & 1581.3 & 1.06 & 1.12 & 1.15 & 1.08 & 1.16 & 1.19 \\
\hline $100 \times 50 \times 2.5 \mathrm{~L} 550 \mathrm{E} 55$ & 660 & $\mathrm{~L}+\mathrm{F}$ & 99.9 & 5413.6 & 6149.1 & 5813.6 & 1.07 & 1.09 & 1.27 & 1.07 & 1.09 & 1.29 \\
\hline \multirow[t]{5}{*}{$50 \times 100 \times 2.5 \mathrm{~L} 1500^{\#}$} & --- & $\mathrm{L}+\mathrm{F}$ & --- & --- & --- & 8305.2 & --- & --- & --- & 1.16 & 1.16 & 1.50 \\
\hline & \multicolumn{6}{|r|}{ Mean $\left(P_{m}\right)$} & 1.08 & 1.14 & 1.21 & 1.11 & 1.17 & 1.28 \\
\hline & \multicolumn{6}{|r|}{$\operatorname{COV}\left(V_{P}\right)$} & 0.032 & 0.035 & 0.053 & 0.040 & 0.043 & 0.088 \\
\hline & \multicolumn{6}{|c|}{ Resistance factor $\left(\phi_{0}\right)$} & 0.85 & 0.90 & 0.91 & 0.90 & 0.90 & 0.91 \\
\hline & \multicolumn{6}{|c|}{ Reliability index $\left(\beta_{0}\right)$} & 3.13 & 2.87 & 3.04 & 2.98 & 2.96 & 3.10 \\
\hline
\end{tabular}

Note: ${ }^{*}$ Test results from Huang and Young [2]; ${ }^{\#}$ Test results from Huang and Young [5]

$M_{\text {end,Exp }}=P_{E x p}(e+\delta) ; M_{i, E x p}=P_{E x p}\left(e+\delta+\Delta_{u}\right) ; M_{e, E x p}=M_{e n d, E x p} /\left(1-P_{E x p} / P_{e}\right)$

Table 15: Comparison of test strengths with design strengths for Series 100×50×2.5L550 


\begin{tabular}{|c|c|c|c|c|c|c|c|c|c|c|c|c|}
\hline \multirow[b]{2}{*}{ Specimen } & \multicolumn{6}{|c|}{ Test } & \multicolumn{6}{|c|}{ Comparison } \\
\hline & $\begin{array}{c}l_{e} \\
(\mathrm{~mm})\end{array}$ & $\begin{array}{c}\text { Failure } \\
\text { mode }\end{array}$ & $\begin{array}{l}P_{\text {Exp }} \\
(\mathrm{kN})\end{array}$ & $\begin{array}{c}M_{\text {end,Exp }} \\
(\mathrm{kNmm})\end{array}$ & $\begin{array}{c}M_{i, \operatorname{Exp}} \\
(\mathrm{kNmm})\end{array}$ & $\begin{array}{c}M_{e, E x p} \\
(\mathrm{kNmm})\end{array}$ & $\frac{P_{\text {Exp }}}{P_{A S C E}}$ & $\frac{P_{\text {Exp }}}{P_{A S / N Z S}}$ & $\frac{P_{E x p}}{P_{E C 3}}$ & $\frac{M_{e, \text { Exp }}}{M_{A S C E}}$ & $\frac{M_{e, \text { Exp }}}{M_{A S / N Z S}}$ & $\frac{M_{e, E x p}}{M_{E C 3}}$ \\
\hline $100 \times 50 \times 2.5 \mathrm{~L} 1550 \mathrm{E} 5$ & 1660 & $\mathrm{~F}$ & 151.2 & 722.7 & 4455.5 & 2181.9 & 1.03 & 1.13 & 1.23 & 1.09 & 1.39 & 1.68 \\
\hline $100 \times 50 \times 2.5 \mathrm{~L} 1550 \mathrm{E} 12.5$ & 1660 & $\mathrm{~F}$ & 127.8 & 1446.7 & 5260.4 & 3332.1 & 1.06 & 1.15 & 1.26 & 1.14 & 1.33 & 1.61 \\
\hline \multirow[t]{6}{*}{$50 \times 100 \times 2.5 \mathrm{~L} 1500^{\#}$} & --- & $\mathrm{L}+\mathrm{F}$ & --- & --- & --- & 8305.2 & --- & --- & --- & 1.16 & 1.16 & 1.49 \\
\hline & & & & & & Mean $\left(P_{m}\right)$ & 1.04 & 1.13 & 1.27 & 1.09 & 1.37 & 1.76 \\
\hline & & & & & & $\operatorname{COV}\left(V_{P}\right)$ & 0.036 & 0.010 & 0.026 & 0.084 & 0.199 & 0.303 \\
\hline & & & & & Resistance & factor $\left(\phi_{0}\right)$ & 0.85 & 0.90 & 0.91 & 0.90 & 0.90 & 0.91 \\
\hline & & & & & Reliability & index $\left(\beta_{0}\right)$ & 2.95 & 2.92 & 3.37 & 2.66 & 2.41 & 2.34 \\
\hline & & & & & Resistance & factor $\left(\phi_{1}\right)$ & 0.85 & 0.85 & 0.85 & 0.90 & 0.90 & 0.90 \\
\hline
\end{tabular}

Note: ${ }^{*}$ Test results from Huang and Young [2]; ${ }^{\#}$ Test results from Huang and Young [5]

$M_{\text {end,Exp }}=P_{E x p}(e+\delta) ; M_{i, E x p}=P_{E x p}\left(e+\delta+\Delta_{u}\right) ; M_{e, E x p}=M_{e n d, E x p} /\left(1-P_{E x p} / P_{e}\right)$

Table 16: Comparison of test strengths with design strengths for Series $100 \times 50 \times 2.5 \mathrm{~L} 1550$ 


\begin{tabular}{|c|c|c|c|c|c|c|c|c|c|c|c|c|}
\hline \multirow[b]{2}{*}{ Specimen } & \multicolumn{6}{|c|}{ Test } & \multicolumn{6}{|c|}{ Comparison } \\
\hline & $\begin{array}{c}l_{e} \\
(\mathrm{~mm})\end{array}$ & $\begin{array}{c}\text { Failure } \\
\text { mode }\end{array}$ & $\begin{array}{l}P_{\text {Exp }} \\
(\mathrm{kN})\end{array}$ & $\begin{array}{c}M_{\text {end,Exp }} \\
(\mathrm{kNmm})\end{array}$ & $\begin{array}{c}M_{i, \text { Exp }} \\
(\mathrm{kNmm})\end{array}$ & $\begin{array}{c}M_{e, \operatorname{Exp}} \\
(\mathrm{kNmm})\end{array}$ & $\frac{P_{E x p}}{P_{A S C E}}$ & $\frac{P_{E x p}}{P_{A S / N Z S}}$ & $\frac{P_{E x p}}{P_{E C 3}}$ & $\frac{M_{e, E x p}}{M_{A S C E}}$ & $\frac{M_{e, E x p}}{M_{A S / N Z S}}$ & $\frac{M_{e, E \times p}}{M_{E C 3}}$ \\
\hline $150 \times 50 \times 2.5 \mathrm{~L} 550 \mathrm{E} 5$ & 660 & $\mathrm{~L}+\mathrm{F}$ & 290.8 & 1317.3 & 2446.9 & 1542.4 & 0.96 & 1.04 & 1.01 & 0.95 & 1.05 & 1.01 \\
\hline $150 \times 50 \times 2.5 \mathrm{~L} 550 \mathrm{E} 12.5$ & 660 & $\mathrm{~L}+\mathrm{F}$ & 217.7 & 2832.3 & 3869.4 & 3175.6 & 0.98 & 1.04 & 0.99 & 0.98 & 1.05 & 0.99 \\
\hline $150 \times 50 \times 2.5 \mathrm{~L} 550 \mathrm{E} 25$ & 660 & $\mathrm{~L}+\mathrm{F}$ & 173.9 & 4104.0 & 5178.1 & 4496.5 & 1.05 & 1.10 & 1.04 & 1.06 & 1.11 & 1.04 \\
\hline \multirow[t]{6}{*}{$50 \times 150 \times 2.5 \mathrm{~L} 1500^{\#}$} & --- & $\mathrm{L}+\mathrm{F}$ & --- & --- & --- & 9085.9 & --- & --- & --- & 1.27 & 1.27 & 1.21 \\
\hline & \multicolumn{6}{|c|}{ Mean $\left(P_{m}\right)$} & 1.00 & 1.06 & 1.02 & 1.04 & 1.11 & 1.06 \\
\hline & \multicolumn{6}{|c|}{$\operatorname{COV}\left(V_{P}\right)$} & 0.072 & 0.043 & 0.027 & 0.130 & 0.082 & 0.076 \\
\hline & \multicolumn{6}{|c|}{ Resistance factor $\left(\phi_{0}\right)$} & 0.85 & 0.90 & 0.91 & 0.90 & 0.90 & 0.91 \\
\hline & \multicolumn{6}{|c|}{ Reliability index $\left(\beta_{0}\right)$} & 2.57 & 2.55 & 2.46 & 2.26 & 2.57 & 2.41 \\
\hline & \multicolumn{6}{|c|}{ Resistance factor $\left(\phi_{1}\right)$} & 0.85 & 0.85 & 0.85 & 0.90 & 0.90 & 0.90 \\
\hline
\end{tabular}

Note: ${ }^{*}$ Test results from Huang and Young [2]; ${ }^{\#}$ Test results from Huang and Young [5]

$M_{\text {end,Exp }}=P_{E x p}(e+\delta) ; M_{i, E x p}=P_{E x p}\left(e+\delta+\Delta_{u}\right) ; M_{e, E x p}=M_{e n d, E x p} /\left(1-P_{E x p} / P_{e}\right)$

Table 17: Comparison of test strengths with design strengths for Series $150 \times 50 \times 2.5 \mathrm{~L} 550$ 


\begin{tabular}{|c|c|c|c|c|c|c|c|c|c|c|c|c|}
\hline \multirow[b]{2}{*}{ Specimen } & \multicolumn{6}{|c|}{ Test } & \multicolumn{6}{|c|}{ Comparison } \\
\hline & $\begin{array}{c}l_{e} \\
(\mathrm{~mm})\end{array}$ & $\begin{array}{c}\text { Failure } \\
\text { mode }\end{array}$ & $\begin{array}{l}P_{\text {Exp }} \\
(\mathrm{kN})\end{array}$ & $\begin{array}{c}M_{\text {end,Exp }} \\
(\mathrm{kNmm})\end{array}$ & $\begin{array}{c}M_{i, E x p} \\
(\mathrm{kNmm})\end{array}$ & $\begin{array}{c}M_{e, \operatorname{Exp}} \\
(\mathrm{kNmm})\end{array}$ & $\frac{P_{E x p}}{P_{A S C E}}$ & $\frac{P_{E x p}}{P_{A S / N Z S}}$ & $\frac{P_{E x p}}{P_{E C 3}}$ & $\frac{M_{e, E x p}}{M_{A S C E}}$ & $\frac{M_{e, E x p}}{M_{A S / N Z S}}$ & $\frac{M_{e, E x p}}{M_{E C 3}}$ \\
\hline $150 \times 50 \times 2.5 \mathrm{~L} 1550 \mathrm{E} 2$ & 1660 & $\mathrm{~L}+\mathrm{F}$ & 218.6 & 487.5 & 2654.4 & 1531.6 & 1.16 & 1.24 & 1.21 & 1.51 & 1.75 & 1.65 \\
\hline $150 \times 50 \times 2.5 \mathrm{~L} 1550 \mathrm{E} 5$ & 1660 & $\mathrm{~L}+\mathrm{F}$ & 188.5 & 857.7 & 3275.3 & 2127.7 & 1.14 & 1.20 & 1.15 & 1.34 & 1.50 & 1.38 \\
\hline $150 \times 50 \times 2.5 \mathrm{~L} 1550 \mathrm{E} 55$ & 1660 & $\mathrm{~L}+\mathrm{F}$ & 75.3 & 4175.4 & 6559.3 & 5443.3 & 1.08 & 1.11 & 1.03 & 1.10 & 1.14 & 1.04 \\
\hline \multirow[t]{5}{*}{$50 \times 150 \times 2.5 \mathrm{~L} 1500^{\#}$} & --- & $\mathrm{L}+\mathrm{F}$ & --- & --- & --- & 9085.9 & --- & --- & --- & 1.27 & 1.27 & 1.20 \\
\hline & \multicolumn{6}{|c|}{ Mean $\left(P_{m}\right)$} & 1.11 & 1.17 & 1.12 & 1.26 & 1.38 & 1.30 \\
\hline & \multicolumn{6}{|r|}{$\operatorname{COV}\left(V_{P}\right)$} & 0.031 & 0.041 & 0.057 & 0.105 & 0.151 & 0.171 \\
\hline & \multicolumn{6}{|c|}{ Resistance factor $\left(\phi_{0}\right)$} & 0.85 & 0.90 & 0.91 & 0.90 & 0.90 & 0.91 \\
\hline & \multicolumn{6}{|c|}{ Reliability index $\left(\beta_{0}\right)$} & 3.24 & 2.96 & 2.71 & 3.10 & 2.89 & 2.49 \\
\hline
\end{tabular}

Note: ${ }^{*}$ Test results from Huang and Young [2]; ${ }^{\#}$ Test results from Huang and Young [5]

$M_{\text {end,Exp }}=P_{E x p}(e+\delta) ; M_{i, E x p}=P_{E x p}\left(e+\delta+\Delta_{u}\right) ; M_{e, E x p}=M_{e n d, E x p} /\left(1-P_{E x p} / P_{e}\right)$

Table 18: Comparison of test strengths with design strengths for Series $150 \times 50 \times 2.5 \mathrm{~L} 1550$ 


\begin{tabular}{|c|c|c|c|c|c|c|}
\hline & $\frac{P_{E x p}}{P_{A S C E}}$ & $\frac{P_{E x p}}{P_{A S / N Z S}}$ & $\frac{P_{E x p}}{P_{E C 3}}$ & $\frac{M_{e, E x p}}{M_{A S C E}}$ & $\frac{M_{e, \text { Exp }}}{M_{A S / N Z S}}$ & $\frac{M_{e, E x p}}{M_{E C 3}}$ \\
\hline Number of tests & 45 & 45 & 45 & 53 & 53 & 53 \\
\hline Mean $\left(P_{m}\right)$ & 1.09 & 1.16 & 1.22 & 1.16 & 1.30 & 1.47 \\
\hline $\operatorname{COV}\left(V_{P}\right)$ & 0.080 & 0.065 & 0.103 & 0.125 & 0.130 & 0.234 \\
\hline Resistance factor $\left(\phi_{0}\right)$ & 0.85 & 0.90 & 0.91 & 0.90 & 0.90 & 0.91 \\
\hline Reliability index $\left(\beta_{0}\right)$ & 3.04 & 2.90 & 2.97 & 2.83 & 3.04 & 2.82 \\
\hline Resistance factor $\left(\phi_{1}\right)$ & 0.85 & 0.85 & 0.85 & 0.90 & 0.90 & 0.90 \\
\hline Reliability index $\left(\beta_{1}\right)$ & 3.04 & 3.34 & 3.37 & 2.83 & 3.23 & 2.96 \\
\hline
\end{tabular}

Table 19: Comparison of test strengths with design strengths for all beam-column specimens 

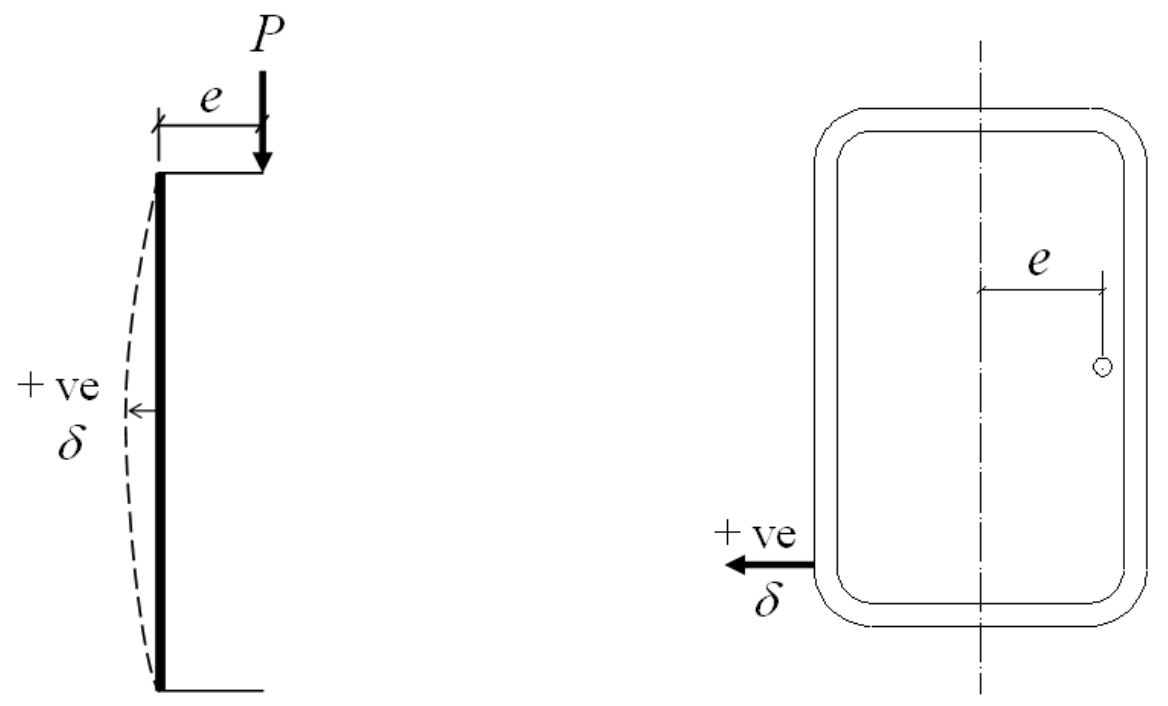

Figure 1: Sign convention and location of overall geometric imperfection measurements

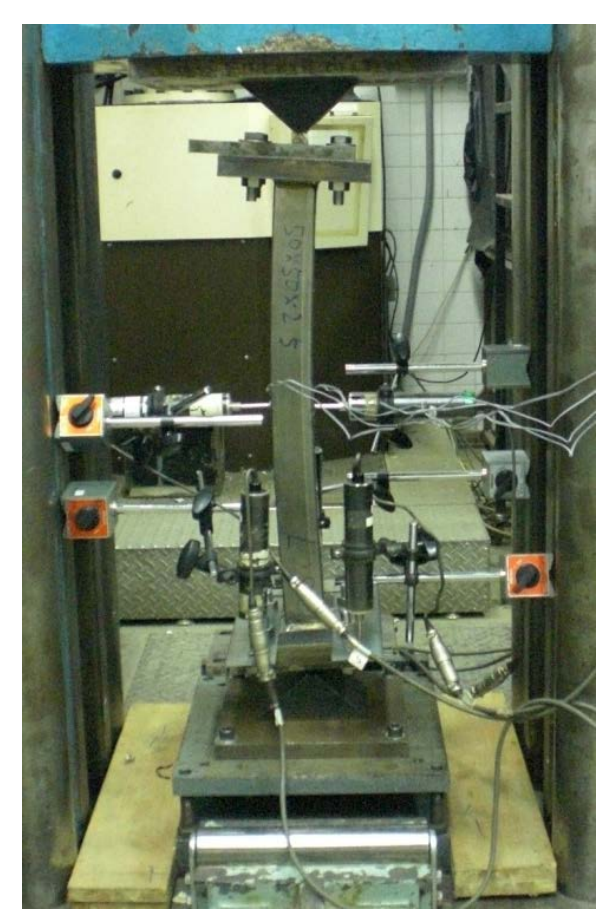

(a) Test rig

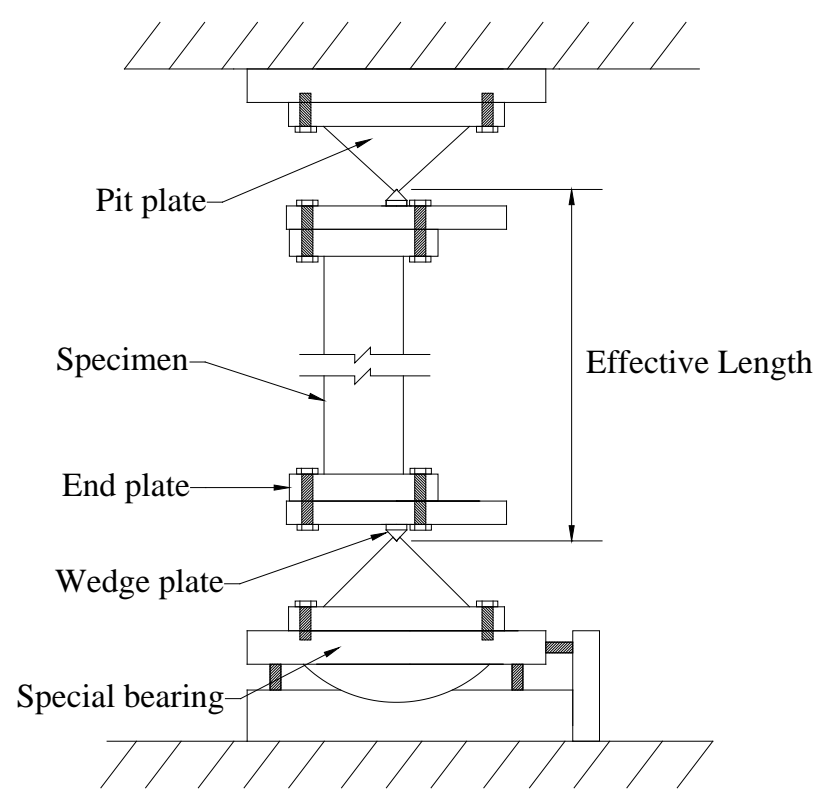

(b) Setup

Figure 2: Schematic view of beam-column test 


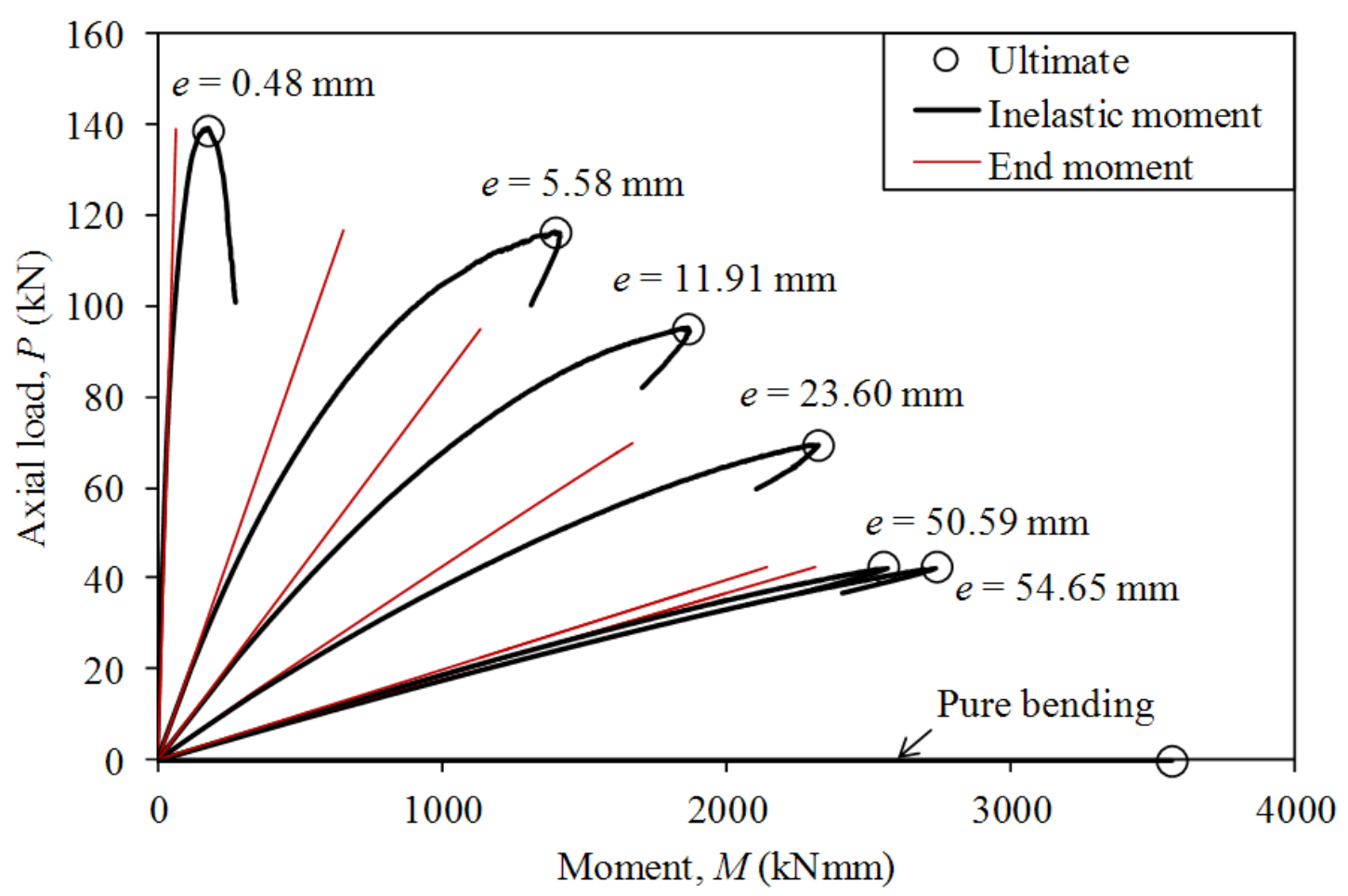

Figure 3: Axial load versus moment curve for Series $50 \times 50 \times 1.5 \mathrm{~L} 550$

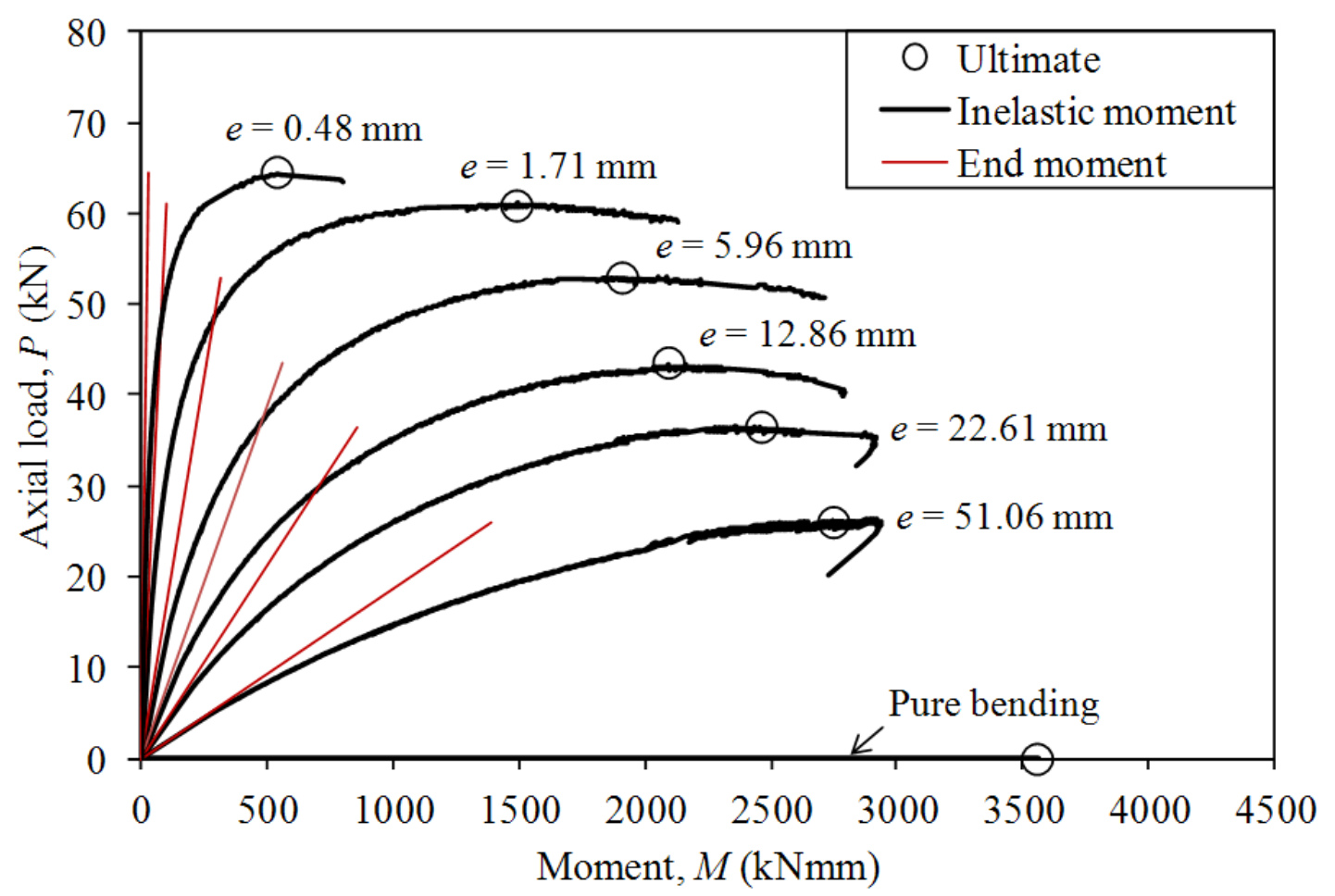

Figure 4: Axial load versus moment curve for Series $50 \times 50 \times 1.5 \mathrm{~L} 1550$ 


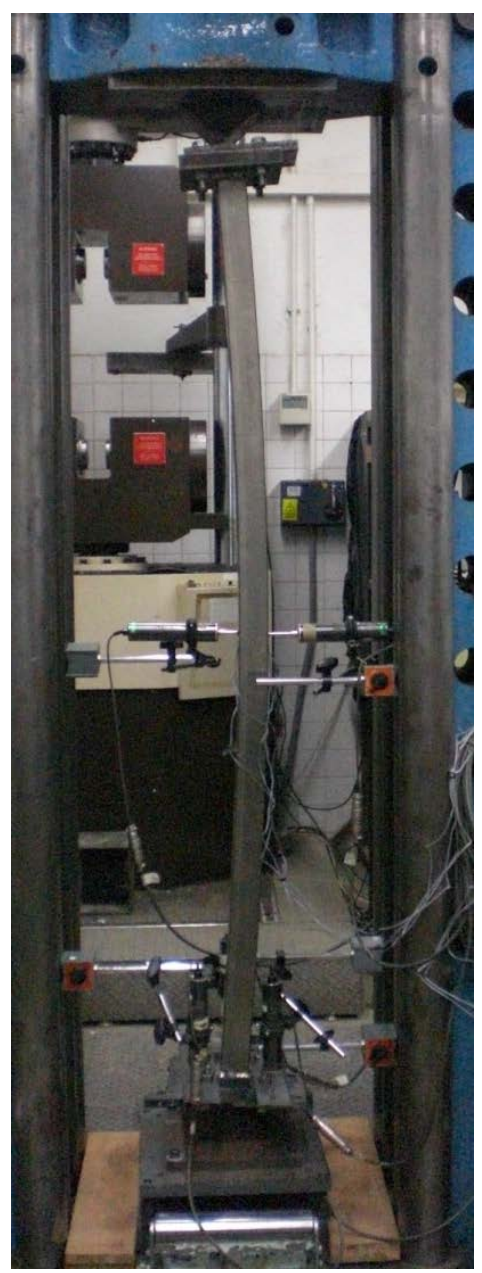

(a)

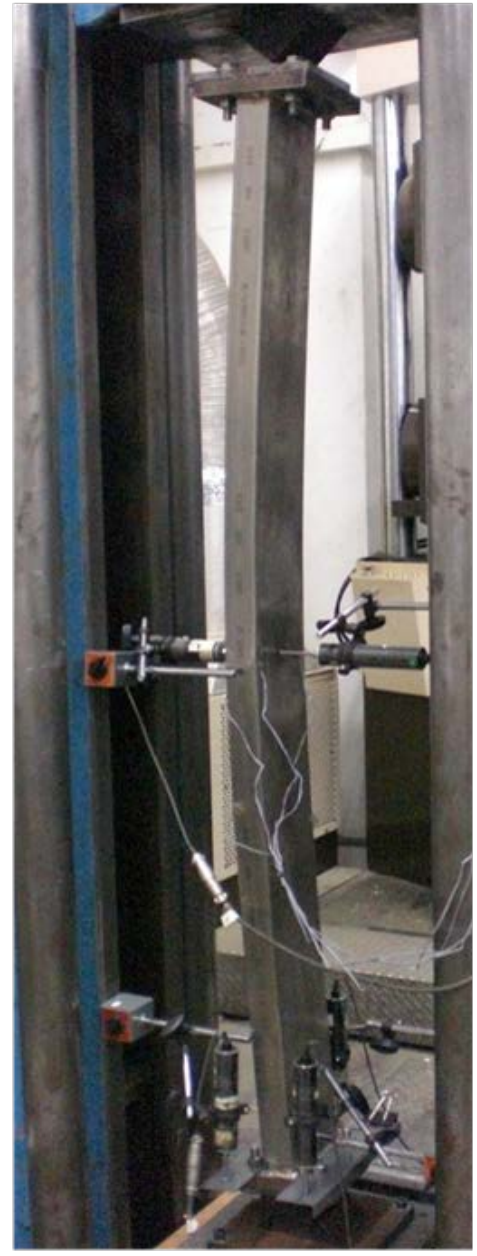

(b)

Figure 5: (a) Flexural buckling of specimen 50×50×2.5L1550E5 (b) Interaction of local and flexural buckling of specimen $150 \times 50 \times 2.5 \mathrm{~L} 1550 \mathrm{E} 25$ 


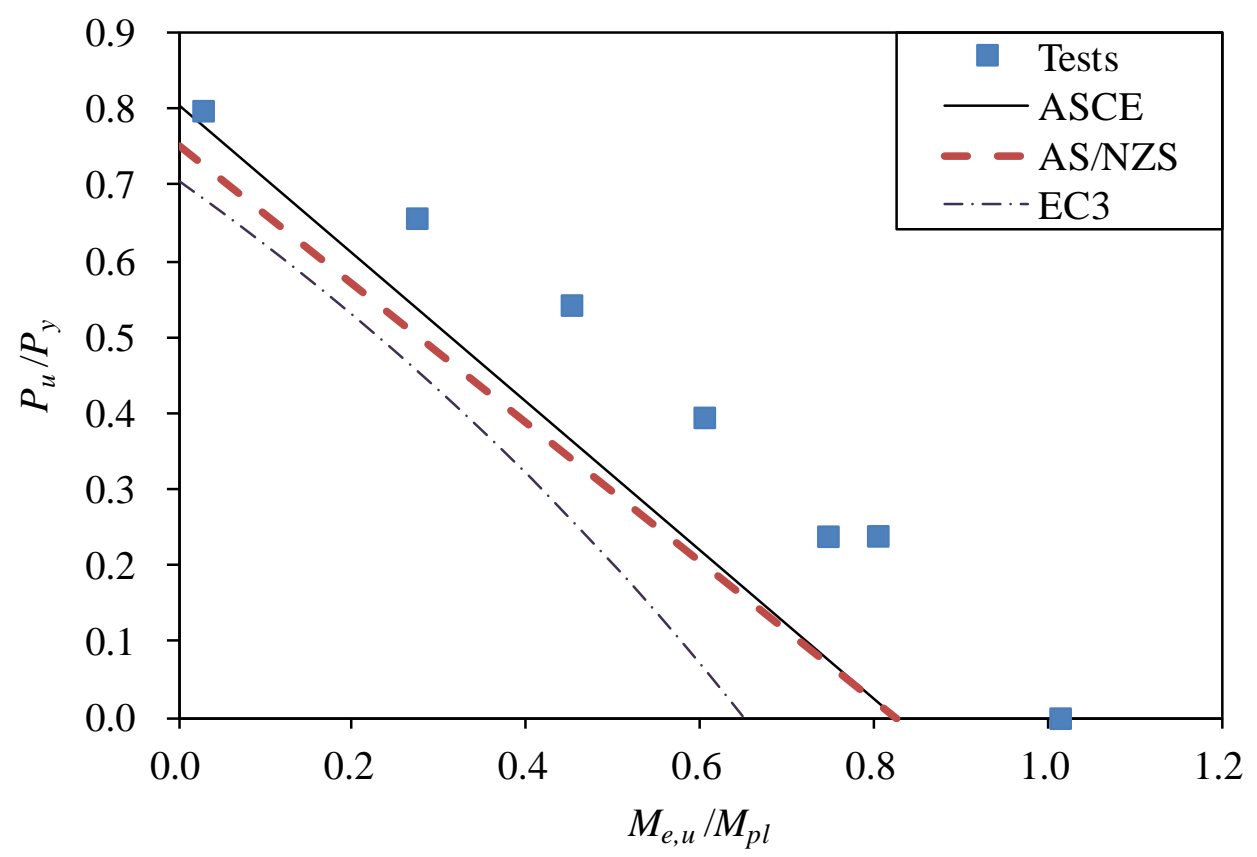

Figure 6: Interaction curve of Series 50×50×1.5L550

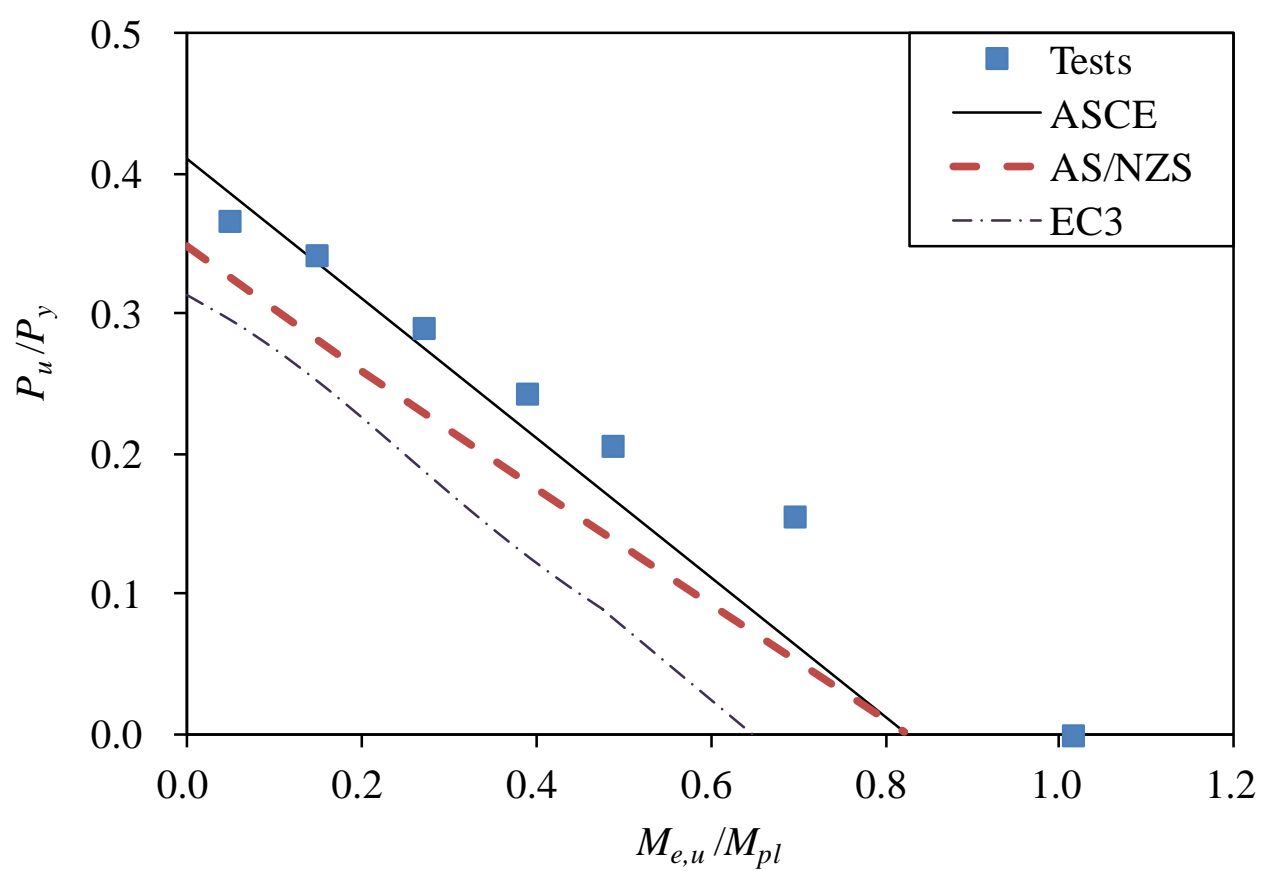

Figure 7: Interaction curve of Series $50 \times 50 \times 1.5 \mathrm{~L} 1550$ 


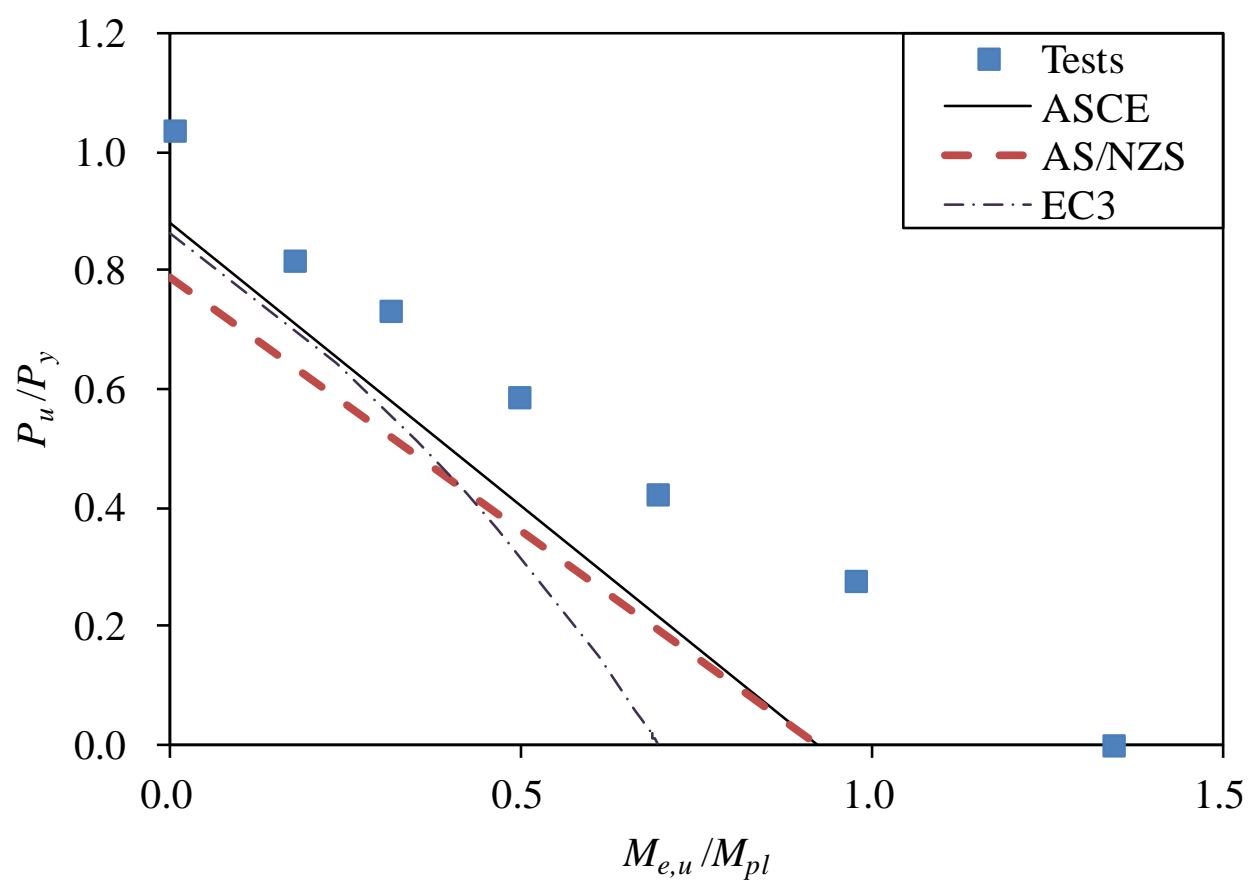

Figure 8: Interaction curve of Series 50×50×2.5L550

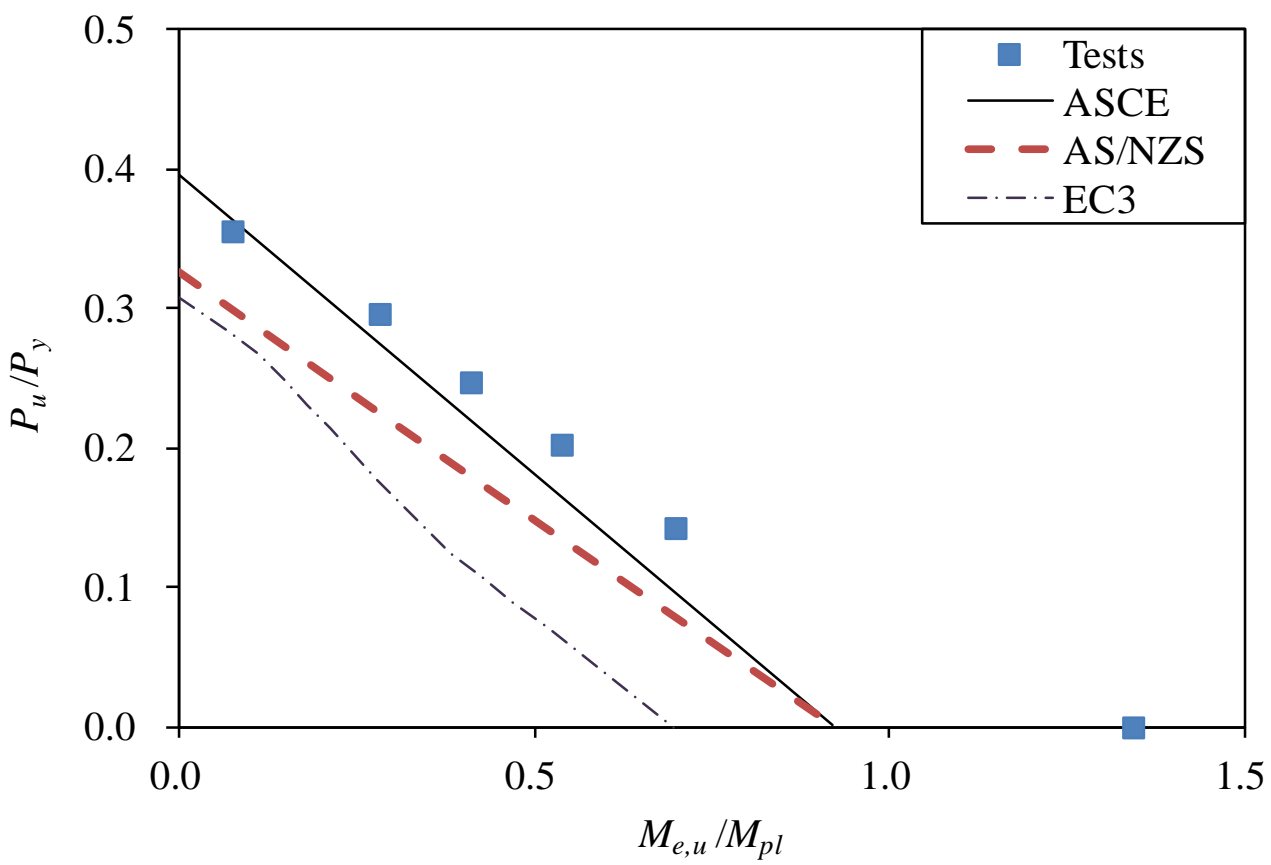

Figure 9: Interaction curve of Series 50×50×2.5L1550 


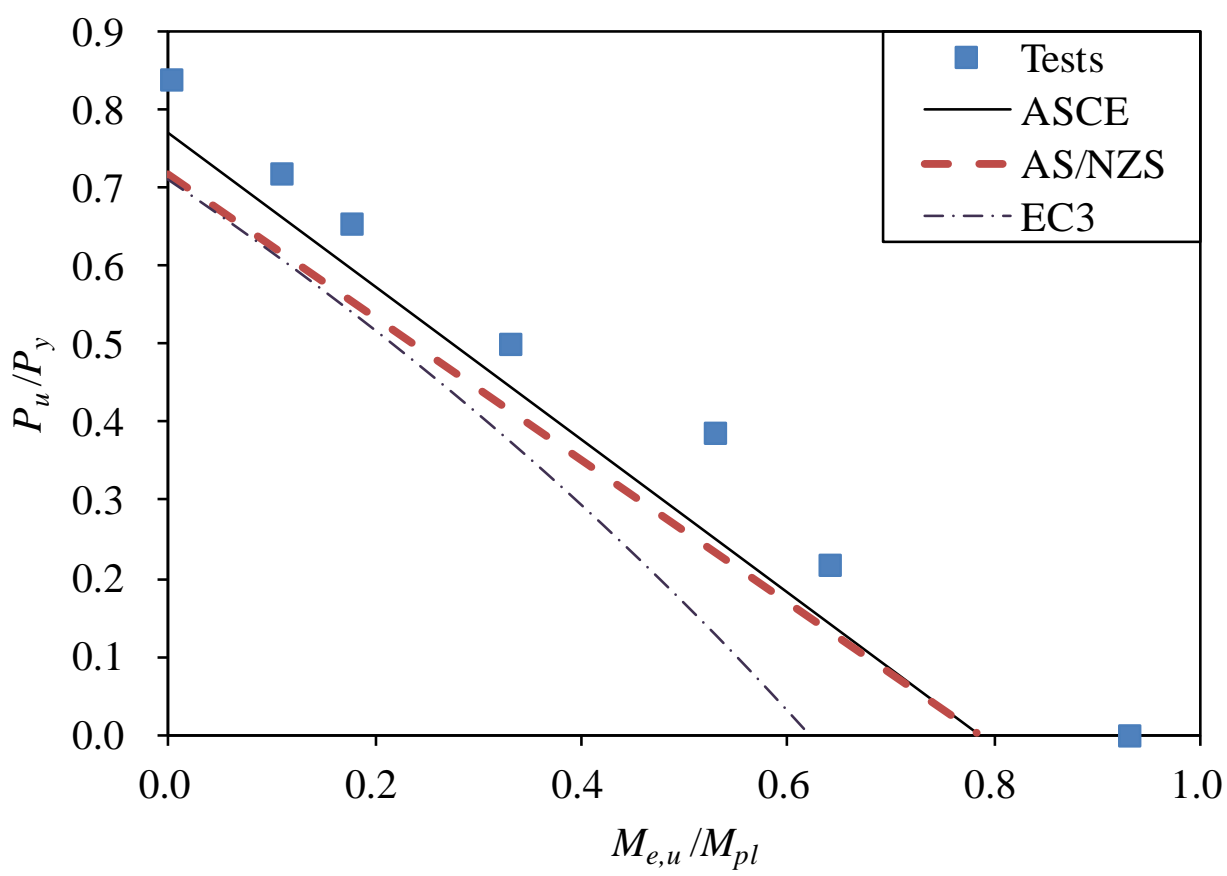

Figure 10: Interaction curve of Series $100 \times 50 \times 2.5 \mathrm{~L} 550$

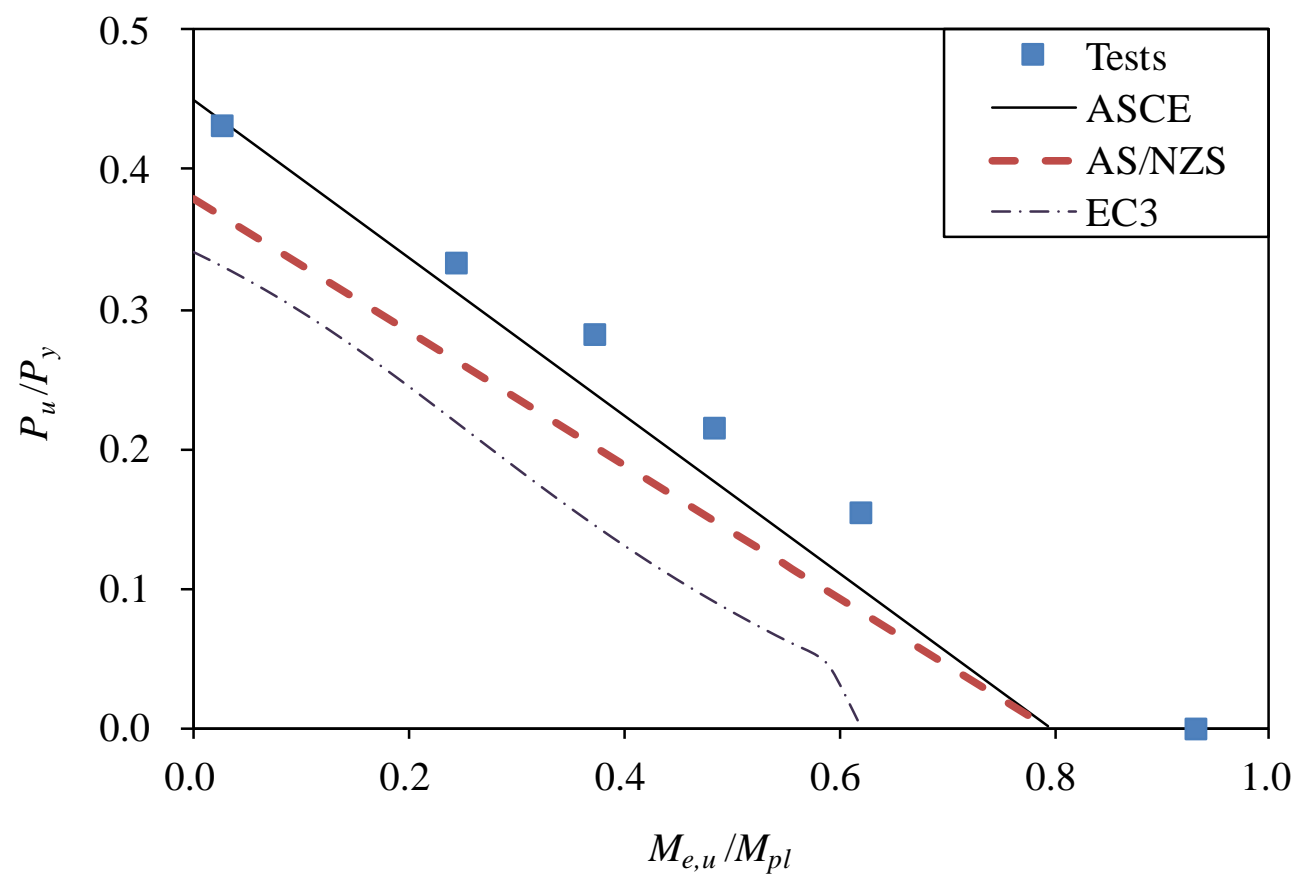

$\underline{\text { Figure 11: Interaction curve of Series } 100 \times 50 \times 2.5 \mathrm{~L} 1550}$ 


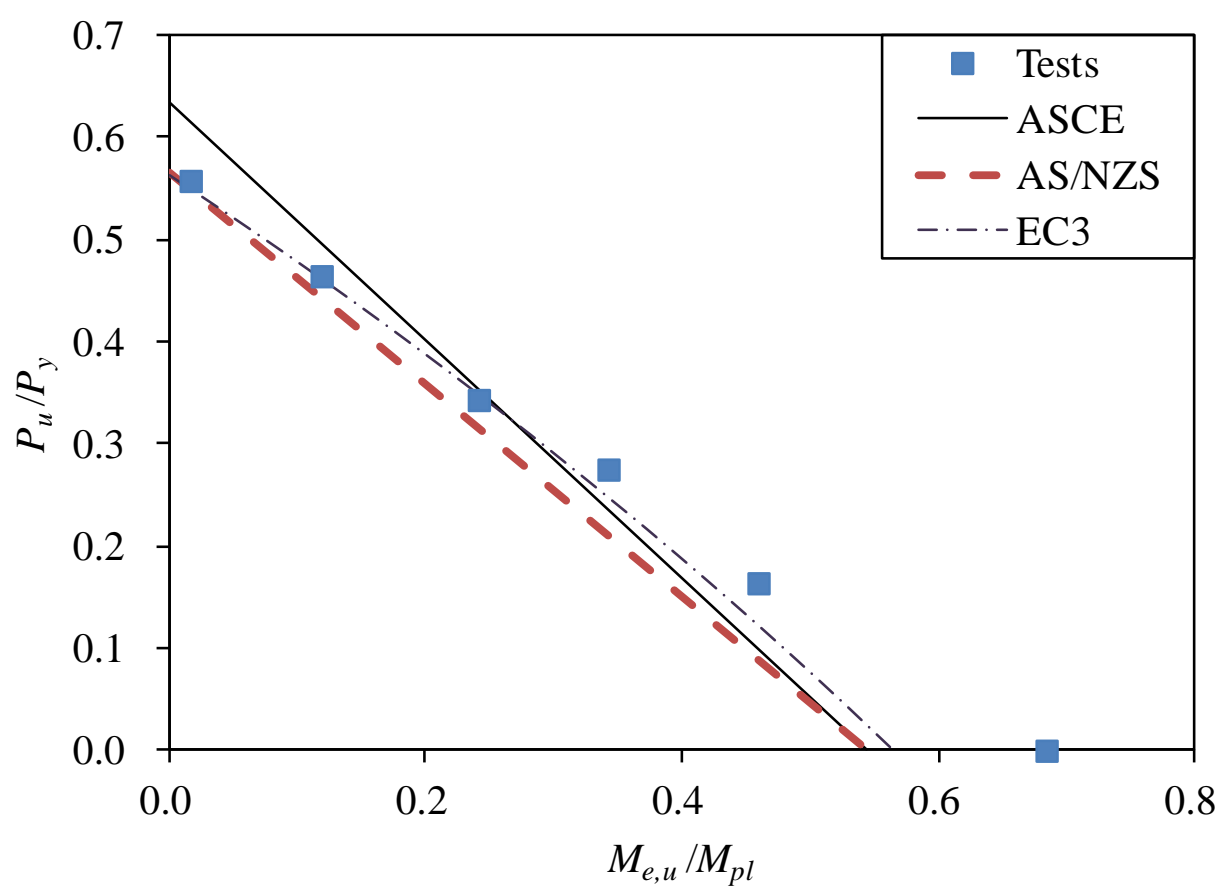

Figure 12: Interaction curve of Series $150 \times 50 \times 2.5 \mathrm{~L} 550$

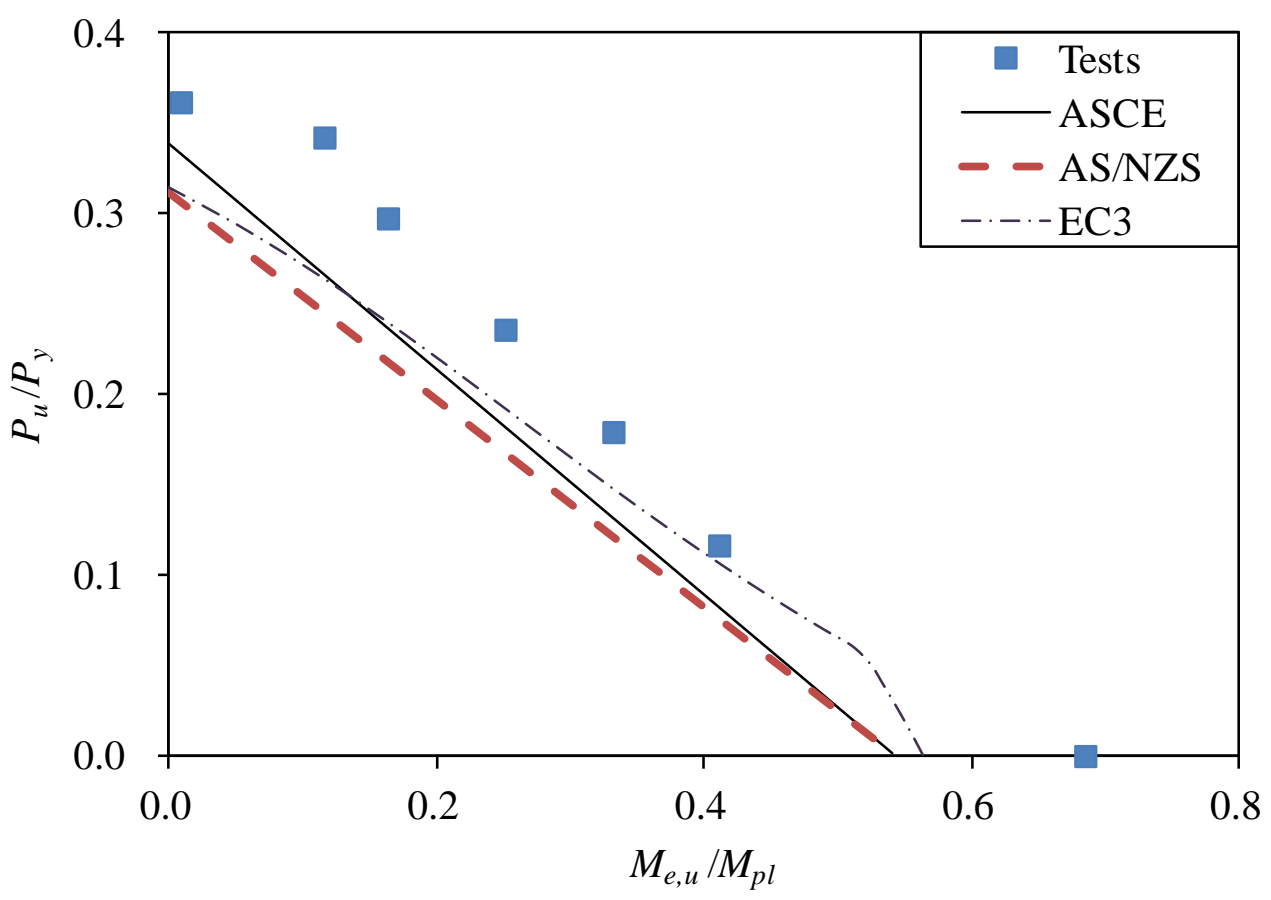

Figure 13: Interaction curve of Series $150 \times 50 \times 2.5 \mathrm{~L} 1550$ 